\title{
Spillovers from High-Skill Consumption to Low-Skill Labor Markets
}

\author{
Francesca Mazzolari, University of California at Irvine and IZA \\ Giuseppe Ragusa, University of California at Irvine
}

April 27, 2007

(This draft: June 19, 2007)

\begin{abstract}
Census data show that low-skill workers in the United States are increasingly employed in the provision of non-tradeable time-intensive services - such as food preparation and cleaning - that can be broadly thought as substitutes of home production activities. Consumer expenditure data show that the fraction of household spending in these services is increasing with the head's wage rate, consistent with the predictions of standard economic theory.

These stylized facts suggest a "consumption story" for how the physical presence and productivity gains of skilled workers might affect the employment and earnings opportunities of unskilled workers. Using the presence of land grant institutions as an instrument for the supply of college graduates (Moretti, 2004), we find that a larger share of skilled individuals in a city workforce is associated with a larger share of unskilled workers being employed in outsourced home production activities. This finding shows that imperfect substitution in production and human capital externalities might not be the only reason why unskilled wages are higher in skilled cities.

We also find that the association between wage growth at the top and wage growth at the bottom of a city wage distribution (with respect to the growth at the median) is larger in cities with a larger proportion of low-wage workers employed in outsourced home production activities in a base year. This finding suggests that the steady increase in the market returns to skill in the last three decades, together with somewhat more sluggish changes in consumption patterns, might provide a viable explanation for some of the wage compression in the lower half of the wage distribution observed in the 1990s (Autor, Katz and Kearney, 2006).
\end{abstract}

Francesca Mazzolari (fmazzola@uci.edu) and Giuseppe Ragusa (gragusa@uci.edu) are both assistant professors of economics at the University of California at Irvine, 3151 Social Science Plaza, Irvine CA 92697-5100.

The authors are grateful to Roger Gordon, David Levine and Giovanni Peri for helpful suggestions. They also thank Joel Elvery and other participants at the Twelfth Annual Meetings of the Society of Labor Economists (Chicago, May 4-5 2007) for useful comments. The authors thank the University of California Labor and Employment Research Fund for financial support. 


\section{Introduction}

Many influential papers have documented a large and ubiquitous widening of the U.S. wage distribution in the 1980s (Bound and Johnson, 1992; Katz and Murphy 1992; Juhn, Murphy and Pierce, 1993). Early consensus was that this phenomenon reflected a secular rise in the demand for skills attributable to skill-biased technological change. ${ }^{1}$ As documented in Autor, Katz and Kearney (2006, 2007), wage inequality has continued to increase in the last fifteen years, this time in an asymmetric way: as in the past, wage growth has been the fastest for top earners, while-in stark contrast with previous trends - it has been higher (or at least not lower) at the bottom than in the middle of the wage distribution. Over the same period, employment shares in both the highest and lowest skill occupations increased, while employment shares in middling occupations contracted. This evidence is hard to reconcile with a simple skill-biased technological change model.

Autor, Katz and Kearney $(2006,2007)$ argue that wage growth polarization is consistent with the more nuanced form of technological change proposed by Autor, Levy and Murnane (2003; ALM henceforth), in which information technology has nonmonotone impacts on the demand for skill throughout the earnings distribution: it raises demand for the non-routine "abstract tasks" used by educated professionals and managers; it reduces demand for the "routine tasks" performed by moderately skilled workers; and it has little direct impact on the non-routine "manual tasks" used in many low-skill jobs. In this framework the secularly declining price of computer capital is the exogenous force that shocks the economy. This is in turn implicitly assumed to produce one aggregate output using a technology in three tasks that can be shown not to be distributed uniformly across the wage distribution. ${ }^{2}$

\footnotetext{
${ }^{1}$ See Katz and Autor (1999) and Acemoglu (2002) for reviews of the large literature on the causes of wage inequality; Krueger (1993) and Berman, Bound and Griliches (1994) for more details on the SBTC hypothesis and Card and DiNardo (2002) for a discussion of problems and puzzles associated with this hypothesis.

${ }^{2}$ The intuition that jobs that can be routinized are not distributed uniformly across the wage distribution is developed in Goos and Manning (2007). They show that, with this extension, the ALM "routinization" hypothesis is a good explanation for the phenomenon of "job polarization" observed in the United Kingdom since 1975. In this framework, the fact that computerization causes manual tasks to grow as a share of labor input can be interpreted as a form of Baumol's disease (1967), arising from the fact that productivity growth is low for non-routine manual tasks
} 
Census data suggest that the manual tasks performed by unskilled individuals in the United States, besides being complements in production in industries where skilled individuals are also employed, can be reasonably modeled as the primary input in a sector that includes time-intensive services like food preparation, cleaning, repair and delivery, which can be broadly defined as market-substitutes for home production activities. Skilled workers (with their high opportunity cost of time) are expected to be net buyers of these services. Consumer expenditure data show that, consistent with this prediction, consumption of these services, as a fraction of total expenditure, increases in an individual's wage rate. These facts suggest that wage gains for skilled workers (and the shifts they induce in individual allocation of time) might affect low-skill labor markets through "consumption spillovers". In particular, the steady growth of wage inequality at the top of the wage distribution in the last three decades (due to some form of skill-biased technological progress, among other forces ${ }^{3}$ ) might have induced a rise in the consumption of outsourced home production tasks that explains some of the increase in relative demand for unskilled work.

This paper investigates the claim that the employment and earnings opportunities of unskilled workers in the United States depend on the consumption choices of skilled workers through their demand of outsourced home production activities. In Section II we discuss a simple theoretical framework that illustrates this "consumption hypothesis". We then provide several pieces of evidence consistent with this framework. In Section III we show that the jobs that can be thought as providing services that substitute for home production activities are concentrated at the bottom of the wage distribution, and that these jobs absorb an increasing share of the employment of low-skill workers in the United States. For instance, using either industry of work or occupation to identify jobs that substitute for home production (e.g., personal and repair services), we find that between 1980 and 2005 the share of U.S. wage earners in the lowest tenth percentile of the wage distribution who are employed in these jobs has increased from twenty to thirty

because technology is not applied there. Spitz-Oener (2006) applies and develops the ALM hypothesis in her study of the process of job polarization in Germany.

3 There is mounting evidence that the growth in wage inequality is increasingly concentrated at the top of the wage distribution (Autor, Katz and Kearney, 2006; Lemieux, 2006b), and that there is a marked increase in the convexity of the relationship between earnings and schooling (Mincer, 1998). The literature has been exploring various explanations, besides technology, for this phenomenon (Piketty and Saez, 2003) and ways to model it (Dechênes, 2006; Lemieux, 2006a). 
percent. Over the same period, the corresponding figures in the highest tenth percentile have remained below three percent.

Section IV provides additional stylized facts, this time on the consumers of the services increasingly performed by low-skill workers. An analysis of data from the Consumer Expenditure Surveys show that the expenditure share of services that substitute for home production activities is increasing with both the education and the hourly wage of the head of the household. This evidence suggests that outsourced home production services are superior goods, consistent with the notion that skilled workers have a comparative advantage in other sectors. A possibility-inconsistent with our hypothesis of feedback between wage growth for top earners and demand for low-skill service tasks - is that beyond a certain earnings threshold, consumption of "home services" may level off. Importantly, the data reveal that the wage-income elasticity of consumption of home services is very high (around one) among households in the top half of the wage-income distribution.

The findings in Section III and Section IV are complementary in characterizing the supply and demand forces in the market of home services. Consumers and providers tend to belong to different skill groups: consumers are predominantly high-skill workers; providers are predominantly low-skill workers. Given that these services cannot be traded outside of a local market, we turn in the final sections to test the predictions of our consumption hypothesis on the city-level relationship between labor outcomes of highskill and low-skill workers. In Section V, we find that a higher share of college graduates in the workforce of a city (as predicted by the presence of a land grant institution) is associated with a higher fraction of low-skill workers employed in outsourced home production activities. While this finding is consistent with the consumption effects we hypothesize, it is not peculiar to (and potentially contradictory to) explanations for the link between concentration of human capital in a city and (low-skill) labor outcomes based on production complementarities and (within-sector) human capital externalities. To the extent that skilled and unskilled workers are imperfect substitutes in production, then a higher share of college graduates in the workforce of a city should be associated with higher productivity of unskilled workers. If there are human capital spillovers, then the productivity of unskilled workers would be expected to be even higher (Moretti 
2004a, 2004b). Assuming that spillovers are stronger within sectors, ${ }^{4}$ both production complementarities and human capital spillovers predict that uneducated workers should be more productive (and more likely to be employed) in those industries where the skilled workers are also more likely to be employed. On the contrary, as shown in Section III, outsourced home production activities are the sector with the lowest concentration of skilled workers.

Finally, Section VI estimates the relationship across cities between relative wage growth at the top of the wage distribution and relative wage growth at the bottom (both with respect to the growth at median) over the period 1980-2005. The consumption hypothesis illustrated in Section II predicts that where and when wage growth is the highest for high-skilled workers, the demand for market substitutes of the output of home production should increase the most, exerting an upward pressure on the wages of the workers-predominantly low-skilled-that deliver these services. Consistent with our story, we find that the association between relative wage growth at the top and relative wage growth at the bottom of a city wage distribution is larger in cities with a larger proportion of low-skilled workers employed in outsourced home production activities in a base year. For example, in a city where this proportion is 20 percent, then a 10 percent increase in the relative wage growth at the $85^{\text {th }}$ percentile is associated with a 4.8 percent increase in the relative wage growth at the $15^{\text {th }}$ percentile; in a city where the proportion is 30 percent, instead, a 10 percent increase in the relative wage growth at the $85^{\text {th }}$ percentile is associated with a 9.2 percent increase in the relative wage growth at the $15^{\text {th }}$ percentile. The strength of the association, on the contrary, does not vary with the share of college graduates in the workforce of a city. We take this as evidence that human capital externalities do not have an effect on unskilled wage growth similar to the one that our story generates.

Based on these different pieces of evidence, we argue that the consumption-driven explanation for low-skill labor outcomes we explore in this paper might contribute to the

\footnotetext{
${ }^{4}$ In favor of this notion, Moretti (2004c) finds evidence that human capital spillovers between manufacturing plants that belong to similar industries are larger than spillovers between manufacturing plants that belong to industries that are different; also, he finds that spillovers between industries that are in the same city and are economically close are larger than spillovers between industries that are in the same city but are economically distant.
} 
recent debate in the literature on wage inequality. Our framework unveils a mechanism through which relative wage gains at the top of the distribution might feedback into more wage compression at the bottom. Given a secular rise in the demand for the cognitive and interpersonal tasks performed by highly educated wage-earners, this approach might contribute an explanation for the recent twisting in wage growth at the bottom of the distribution that is complementary with those based on the non-monotone impact of technological progress. ${ }^{5}$ If we let changes in consumption patterns, or specialization habits within the family, to be somewhat more sluggish than changes in the market returns to skills, then we would expect consumption spillovers to slowly grow over time. This would in turn predict a lag between relative wage growth for skilled workers and induced rise in the demand for low-skill work, which is consistent with wage growth polarization only arising since the early 1990s (Autor, Katz and Kearney, 2006). ${ }^{6}$

Our paper relates to recent findings in the literature that measures changes in the allocation of time. Aguiar and Hurst (2007) document trends in the allocation of time within the United States and find that home production work hours have decreased between 1985 and 2003, predominantly for women-that spent more time in these activities to start with. This is broadly consistent with our intuition, and points to potential extensions to the present analysis. The role of consumption spillovers might be amplified in an analysis that incorporates compositional effects, both in the workforce (e.g., by gender and educational attainment) and in the overall population (by age, for instance).

Our work also relates to the immigration literature. Borjas and Friedberg (2007) show that, as opposed to the continuous decline in the relative earnings of new immigrants observed since the 1960s, the trend reversed in the 1990s, with newcomers doing as well in 2000, relative to natives, as they had twenty years earlier. The turnaround in the relative earnings of new arrivals is found to have occurred primarily at the top and the bottom ends of the skill distribution. As documented in Section III, the low-skill services

\footnotetext{
${ }^{5}$ Cleaning, restaurant work and the other low-skill jobs that are the focus of this paper all involve tasks that machines cannot (yet) perform, so that they represent a subset of those jobs that are expected to absorb an increasing share of labor input because technology has little impact on them (Baumol, 1967).

${ }^{6}$ Explanations based exclusively on the impact of technological change, on the contrary, seem to require that the effects of technological progress on the relative demand for skill changed over time (from monotone in the 1980s to non-monotone in the 1990s).
} 
that are the focus of this paper are immigrant-intensive sectors. Positive demand shifts for unskilled work driven by consumption spillovers might then partly explain the drop in the immigrant-native wage gap observed at the bottom of the distribution. It is well known, however, that immigration greatly increased the supply of high-school dropouts in recent decades (Borjas, 2003), so this explanation might appear to be at variance with the conclusion of Cortes (2006) that immigrant-induced shifts in low-skill labor force decrease the price of immigrant-intensive services, with lower wages being a likely channel through which these effects take place. Cortes' result, however, holds in specifications that use the tendency of immigrants to move to the same areas in which previous immigrants from their country live, to instrument for the endogenous location choices of immigrants (Card, 2001). The cross-sectional correlation between immigrants' concentration and prices is instead positive, consistent with immigrants choosing their location based on the economic opportunities that the city offers, and with the immigrantinduced shifts in labor supply not being large enough to offset positive price (and wage) pressures.

\section{Conceptual framework}

The objective of this section is to illustrate the "consumption hypothesis" we put forward in this paper. Following Manning (2004), we describe the cross-sectional implications of the equilibrium conditions of an economy made up of many cities, each of which has two sectors (a production and a "housework" sector) and two types of workers ("skilled" or "unskilled"). The goal is to show how differences in the share and productivity of skilled workers across local economies can lead to differences in low-skill labor outcomes through consumption as well as production effects.

Suppose that workers have identical preferences defined on the consumption of two composite goods, $y$ and $x$ : the first is produced by firms using a technology in both skilled and unskilled labor; the second includes time-intensive services (such as cooking and cleaning) that the individual can either produce domestically (using her own time), or purchase in the local market (by buying-in someone else's time). As long as skilled workers have a comparative advantage at producing $y$, then housework services traded in the local market can be characterized as a superior good in consumption, but low-skill 
labor-intensive in production. It follows that part of the demand for low-skilled labor in a city comes from the consumption of housework services by high-skill individuals living in the same area. If these "consumption effects" dominate the human capital spillover effects that might exist in the $y$-sector, then low-skill workers in cities with more skilled workers should be more likely to be employed in the $x$-sector. In case of frictions (e.g., not perfect labor mobility), low-skill wage differences might also arise.

The equilibrium conditions hold equally well in a dynamic context. If a city experiences growth in the productivity of skilled workers, then the "consumption channel" predicts an increase in the demand for housework services (performed by lowskill workers) that might lead to a rise in the unskilled wage.

\section{Setup}

Consider an economy with a set of locations ("cities"). Firms produce a good $y$ (that can be sold on the national economy) using a Cobb-Douglas production function $y=A N_{u Y}{ }^{\sigma_{u}} N_{s Y}{ }^{\sigma_{s}}$, where $N_{j Y}$ is the number of workers of skill $j=u, s$ working in the $y$ sector. ${ }^{7}$ Labor markets are competitive. Cities might differ in the productivity of labor (as measured by the $\sigma$ 's) because of technological differences or pre-existing advantages such as natural resources, proximity to infrastructures or universities. For example, consider the case of two cities, $\mathrm{C}_{1}$ and $\mathrm{C}_{2}$, and suppose that skilled workers are particularly productive in $\mathrm{C}_{1}$, so that demand for them is high. Then, the share of skilled workers is higher in city $\mathrm{C}_{1}$ than in city $\mathrm{C}_{2}$, skilled wages $w_{s}$ are higher because skilled workers are more productive, and unskilled wages $w_{u}$ are higher as well, because of complementarity. If in addition we allow for the existence of human capital externalities, then wages of both skilled and unskilled workers will be higher in $C_{1}$ than $C_{2}$ also because of spillovers. ${ }^{8}$ If workers are assumed to be perfectly mobile, in order for them to

\footnotetext{
${ }^{7}$ The Cobb-Douglas technology is chosen to show that unskilled and skilled labor inputs are complements in production in the $y$-sector, but the results hold in the more general case of CES function. Also, inclusion of physical capital would not affect the results, because it is reasonable to assume that physical capital moves to equalize its rate of return across cities.

${ }^{8}$ Following Moretti (2004a, 2004b and 2004c), we can introduce the possibility of human capital spillovers by allowing $A$ to depend on the fraction of skilled workers in the city: $A=a(S)$, where $S=\frac{N_{s}}{N_{u}+N_{s}}$, and $\delta a / \delta S \geq 0$.
} 
be indifferent between more and less productive locations, land prices must be higher in more productive places.

In each city there is also assumed to be a "housework" sector, the output of which can only be locally traded. In this sector workers are assumed to (i) be equally productive, across types and cities, and to (ii) have the choice to either produce the good domestically using their own time $\left(x_{h}\right)$, or to purchase it in the local market from private household workers $\left(x_{m}\right)$. In the latter case, they might incur an "agency" cost $c \geq 0$ per unit purchased. ${ }^{9}$ Individuals maximize their utility $V(y, x, L)$ - where $x=x_{m}+x_{h}$, and $L$ is leisure-under two constraints: the budget constraint $p_{y} y+p_{x m} x_{m}=w_{j} T_{m}+V_{j}$, where $w_{j}$ and $V_{j}$ are the wage rate and non-labor income for individuals of skill $j$; and the time constraint $T_{m}+T_{h}+L=1$, where $T_{m}$ is market time and $T_{h}$ is work at home time. ${ }^{10}$ In this framework, the choice of the optimal bundle $(y, x, L)$ is governed by preferences and relative prices prevailing in the market. The allocation of work time between home and market (and the composition of $x$ between $x_{h}$ and $x_{m}$ ) is determined instead by an individual's productivity in home production relative to her shadow price of time, represented by the wage rate $w_{j}, j=u, s$. Given that $w_{s}>w_{u}$ (from productivity differences in the $y$-sector), skilled workers are predicted to do less home production than unskilled workers, and consume more $x_{m}$ relative to $x_{h}$. In particular, in this setting a market sector for $x$ will exist if and only if no skilled worker performs paid work in it, because if they did, then it would always be convenient for both types of workers to do the housework themselves. The unskilled workers, on the contrary, might be employed in both sectors, so that the wage at which domestic help can be hired is the unskilled wage $w_{u}$.

If for simplicity we assume that the "agency" cost $c$ is such that $\bar{c}_{u}<c<\bar{c}_{s}$, where $\bar{c}_{j}$ is the threshold above which workers of skill $j=u, s$ find it optimal not to purchase any

\footnotetext{
${ }^{9}$ The cost might arise from a standard principal-agent problem, or it might simply reflect tax wedges.

${ }^{10}$ As in Gronau (1977), we are assuming perfect substitutability between market goods and home products, and between work in the market and work at home. The assumption is needed to guarantee a solution to the model, but it is unrealistic in ruling out the possibility that an individual may attach extra value to goods produced by herself rather than someone else, and that some housework activities provide extra benefits beyond the consumption value of household production. These shortcomings are clear in the case of childcare. See Graham and Green (1984) and Kerkhofs and Kooreman (2003) for attempts to address them. These problems do not affect our basic results, however, as long as there is a nontrivial number of activities for which the assumptions are plausible. This is likely to be the case for activities like cleaning the house, doing the laundry, maintenance and repair services and waste management.
} 
service in the market, then the market demand for household services $X_{m}{ }^{D}$ is given by the sum of the individual demand schedules of skilled individuals, $x_{m}{ }^{d}$. This, in turn, is an increasing function of a worker's opportunity cost of household production (that is, her own wage $w_{s}$ ) and a decreasing function of the cost of purchasing the services in the market: $X_{m}{ }^{D}=N_{s} x_{m}{ }^{d}=N_{s} f\left(w_{s}, w_{u}, c\right), \delta f / \delta w_{s}>0, \delta f / \delta w_{u}<0, \delta f / \delta c<0$.

\section{$\underline{\text { Cross-sectional predictions }}$}

In equilibrium workers are indifferent between working in different sectors, so wages are equalized. If $y$ is nationally traded and firms are perfectly mobile, then the unskilled wage will be equal to the marginal productivity of the unskilled workers in the $y$-sector. The number working in the non-traded household sector will depend on the demand for home goods by the skilled workers at this wage, $X_{m}{ }^{D}$. So, the consumption mechanism highlighted in this model delivers the following prediction:

Prediction 1: the fraction of unskilled workers employed in the non-traded housework sector is increasing in the share of skilled workers in the city.

Even if the model is very stylized (in assuming that (i) skilled and unskilled workers are equally effective in the housework sector, and that (ii) only skilled workers buy-in time), Prediction 1 would arise from the consumption mechanism we have described under weaker assumptions, as long as housework services are items that make up a larger proportion of consumption as income rises. In Section IV we analyze consumption expenditure data and provide evidence in favor of these services being, indeed, superior goods.

While Prediction 1 follows from the consumption mechanism we highlight in this paper, it does not necessarily arise from the effects of the skilled share coming through the production of the composite good $y$. On one hand, if the share of skilled workers is higher in city $C_{1}$ than in city $C_{2}$ because in $C_{1}$ skilled workers are particularly productive at producing $y$, then this sector will be high-skill intensive, and Prediction 1 might arise from this channel as well. On the other hand, however, if production complementarities and human capital spillovers are strong enough, then they might predict the opposite. To test Prediction 1, in Section V we study the cross-sectional association between skilled share and employment shares of unskilled workers across sectors. To rule out the potential bias in favor of Prediction 1 that arises when cross-city variation in the skilled 
share is driven by unobserved demand factors, we use the location of land-grant institutions as a shifter of the supply of skilled workers across cities (Moretti, 2004b).

If we allow frictions in the model, the consumption mechanism we have described might also explain cross-city differences in unskilled wages. Firms might not be perfectly mobile. ${ }^{11}$ Importantly, empirical evidence shows that it is reasonable to assume limited labor mobility among the low-skill workforce (Bound and Holzer, 2000). Then, larger demand for low-skill services consumed by skilled workers might result in higher unskilled wages:

Prediction 2: the wage of the unskilled is non-decreasing in the share of skilled workers in the city.

The same prediction, however, would arise from production complementarities and human capital externalities in the production sector, so that Prediction 2 alone cannot serve as a way to separate between consumption and production effects. It is nevertheless important in showing how some of the positive association between skilled share and (unskilled) wages across cities - that has been traditionally attributed to production complementarities and human capital spillovers-might potentially arise from a consumption channel, the more so over time.

\section{Dynamic predictions}

We have discussed so far the cross-sectional implications of our stylized theoretical setting. We now use it to derive the predicted effects of changes in skilled wages on the employment and earnings opportunities of unskilled workers. These changes might be due to skilled-biased technological progress or any other factor that enhances the marginal productivity of skilled workers.

Nation-wide skill-biased changes in the production goods sector $\left(\Delta \sigma_{s}>\Delta \sigma_{u}\right)$ raise the wage differential between skilled and unskilled workers payable by the production goods sector. In our framework, this will increase the demand (by skilled workers) for unskilled work in the housework sector, leading to the following prediction:

\footnotetext{
${ }^{11}$ Berry and Glaser (2005) present a model of urban agglomeration in which the fixed nature of firms might arise if entrepreneurs want to stay in their cities for consumption reasons or if the innovation makes use of unique aspects of their own urban environment.
} 
Prediction 3: skilled workers are increasingly employed in the (traded) production sector, while unskilled workers are increasingly employed in the (non-traded) housework sector.

In Section III we test this prediction by studying changes in the distribution across sectors of the workforce with different skills. We also study the evolution of relative wages across sectors, to test whether the (unskilled) relative wage payable by the housework sector has increased over time, as our framework would predict.

In cross-city comparisons, the dynamic prediction of the consumption hypothesis is that where wage growth is the highest for high-skilled workers, the demand for market substitutes for home production should increase the most, potentially exerting an upward pressure on the wages of the workers-predominantly low-skilled-that deliver these services. In Section VI we use cross-city variation in the growth of wages at different points of the wage distribution to test the following prediction:

Prediction 4: the relative wage growth experienced by unskilled workers is nondecreasing in the relative wage growth experienced by skilled workers in the city.

\section{Jobs that deliver services that substitute for home production activities: data and stylized facts}

In taking the stylized model of the previous section to the data, decisions need to be made about the empirical counterpart of the theoretical constructs. We define skills either in terms of educational achievement (high-school drop-outs, high-school graduates, individuals with some college education but no degree, and college graduates) or of relative position in the wage distribution (wage-earners at different percentiles of the wage distribution).

We use either industry of work or occupation to identify those jobs that can be thought as delivering goods and services that substitute for home production. Table A1 (in Appendix) provides details on the mapping between industrial classification and nine categories of employment. The first category refers to the jobs that are the focus of our analysis ("home services" from now on) and includes personal, repair, entertainment, protective, cleaning and child care services. We also identify: other clearly non-traded jobs (e.g., retail trade, except eating and drinking places that belongs to the first group; 
health and social services); clearly traded jobs (agriculture, mining and manufacturing); construction; wholesale, transport and utilities; financial services; business services; public administration; and education. ${ }^{12}$

We alternatively use the occupational classification to identify home services as opposed to other non-tradeable services. As shown in Table A2, home services include private household, food preparation, cleaning and personal service occupations, while other non-tradeable jobs include sales and health service occupations.

Table 1 and Table 2 report employment shares in different sectors/occupations by education and wage percentile, respectively. ${ }^{13}$ Data come from the IPUMS extracts of the 1980, 1990 and 2000 decennial censuses and the 2005 American Community Survey (Ruggles et al., 2004). There are substantial differences in the employment distributions by skill groups, and these differences have grown over time. Reflecting the sharp employment drops in manufacturing, employment in traded sectors has declined for all skill levels between 1980 and 2005. Among those who have not completed high school, there has been a pronounced shift towards non-traded activities, entirely driven by the growth of employment in home services. Among more educated groups, on the contrary, there has been some growth in other non-traded activities as well, and among college graduates a pronounced shift towards financial and business services. Table 2 shows that occupational differences across skill groups over time are even more marked when skills are identified by a worker's relative position in the wage distribution. Between 1980 and 2005 the fraction of U.S. wage earners in the lowest tenth percentile of the wage distribution employed in home services has increased from 23 to 30 percent, while the fraction employed in business and financial services has remained approximately 8

12 The basic criterion of assignment of non-traded status consists in whether the producer of a good or service has to be located in physical proximity to the consumer for the job to be done. In some cases there is considerable ambiguity in applying the criterion of physical proximity. For instance, many financial and business services are increasingly performed and delivered electronically. While residential construction jobs surely satisfy the proximity requirement, some other construction jobs (e.g., production plants, infrastructures) may fail the proximity requirement, because those financing, or ultimately using the construction projects, are not necessarily local residents. See Manning (2004) for a discussion of more issues related to assigning non-traded status to different industries.

${ }^{13}$ The analysis is restricted to respondents aged 16 through 65 who were employed in the civilian labor force at the time of the survey, were not unpaid family workers, and did not live in group quarters. For consistency with later analyses, the sample is also restricted to respondents who resided in census-defined metropolitan areas. 
percent. Over the same period, the fraction of U.S. wage earners in the highest tenth percentile of the wage distribution employed in home services has remained at 3 percent, while the fraction employed in business and financial services has increased from 8 to 32 percent.

Figure 1 shows the educational distribution of the workforce in different sectors as of 2000. Home services are the sector with the highest concentration of workers without a high school degree (28 percent of the workforce) and the lowest concentration of college graduates (12 percent). Only the workforce in the construction sector has a similar skill composition (25 percent are high school dropouts and 10 percent are college graduates), while in other sectors high-school dropouts are heavily underrepresented and college graduates overrepresented.

Overall, these stylized facts support Prediction 3: unskilled work in the United States is increasingly concentrated in low-skill intensive home services, while skilled work is increasingly concentrated in high-skill intensive sectors. Similar conclusions arise when using occupation instead of industry to identify workers employed in activities that substitute for home production.

Figure 2 shows that home services, together with traded and construction sectors, employ a higher-than-average share of immigrants. Whereas immigrants represented 16 percent of the labor force in 2000, they represented more than 25 percent of the workers in home services. Not surprisingly, the low-skilled immigrants' share in these services is particularly large (equal to 10 percent, that is two times larger than their share in the total labor force).

Table 3 reports different statistics (mean, median, $10^{\text {th }}$ percentile and $90^{\text {th }}$ percentile) for hourly wages by education and sector from 1980 to 2005 . The last two columns report the gap (defined as the ratio) between hourly wages paid in home services and other sectors, at the beginning and the end of the period respectively. For the entire period and for all educational levels, wages in home services are lower than wages in other sectors. This evidence is consistent regardless of the summary statistic we look at, and confirm the well-known fact that home services are traditionally low-paid jobs. The wage gap, however, has declined significantly among low-educated workers (that is, the group that experienced the highest relative increase in employment in home services) while it has 
remained stable or increased in other groups. The positive correlation between wage and employment changes points to the importance of demand shifts.

\section{Consumption items that correspond to services that substitute for home production activities: data and stylized facts}

Who are the customers for the non-traded tasks that represent an increasing share of the employment opportunities of low-skill individuals in the United States? To the extent that these non-traded activities substitute for goods and services that could otherwise be produced at home, the simple model presented in Section II predicts that the consumers should predominantly be high-wage earners, because of their high opportunity cost of time. In this section we test this prediction using data on consumption expenditures of households in the United States.

\section{The Consumer Expenditure Survey (CEX)}

The CEX is currently the only micro-level data reporting comprehensive measures of consumption expenditures for large cross-sections of households in the United States. ${ }^{14}$ It consists of two separate surveys, one based on retrospective interviews about expenditures in the previous twelve months (the Interview Survey, IS thereafter) and one based on weekly diaries (the Diary Survey, DS). The surveys are independent nationally representative samples of the U.S. population. In this paper we use data drawn from the DS samples, because weekly record keeping should more accurately account for the kind of expenditures that we want to focus on. Services that are substitutes for home production activities are likely to constitute small and frequent purchases, difficult to recall over longer periods of time. Some of them (e.g. housekeeping and personal care services) are indeed exclusively surveyed in the DS. ${ }^{15}$

\footnotetext{
${ }^{14}$ The CEX is collected by the Bureau of Labor Statistics mainly to compute weights for the Consumer Price Index (CPI), but it has also been used for studying the evolution of consumption inequality (Cutler and Katz, 1991; Attanasio and Davis, 1996; Krueger and Perri, 2003; Attanasio, 2003; Battistin, 2003; Attanasio, Battistin, Ichimura, 2004).

${ }^{15}$ According to the Bureau of Labor Statistics (2003), even if in principle since 1986 both surveys are almost exhaustive, neither of them is expected to measure accurately all components of consumption. Large and infrequent expenditure items are expected to be better measured in the IS, while frequently purchased and small items are expected to be better measured in the DS (that, until 1986, only collected information on these items).
} 
In the DS, consumer units (that are households) self-report their purchases over two consecutive one-week periods using product-oriented diaries. Individual commodities are identified by several hundreds of Universal Classification Codes (UCC). For each household we calculate a measure of monthly total expenditure. ${ }^{16}$ We identify seven categories of consumption items that are likely to correspond to services that substitute for home production ("home services"): food away from home; drinks away from home; repair and maintenance, delivery, babysitting, housekeeping and personal care services. Table A3 provides details on the way in which UCC's are mapped into these seven categories.

The DS also includes information on household characteristics (e.g. family size and composition) and numerous characteristics for each member in the household (e.g., age, gender, relationship to the reference person, education, employment and wage income in the twelve months before the interview).

\section{Findings}

We report findings from an analysis of the 1996 and 2004 Diary Surveys. ${ }^{17}$ We focus on households headed by individuals at least 18 and no more than 65 who worked for salary in the twelve months before the interview. The family head is conventionally fixed to be the male in all husband/wife families.

In the two years of observation, home services represent a fairly stable fraction of total household expenditures (13 and 14 percent in 1996 and 2004 respectively). Figure 3 shows that in both years the budget share in home services monotonically increases with the education of the head. In 1996, for example, home services represented 9 percent of the total expenditures of households headed by high-school dropouts, but 14 percent of those of households headed by college graduates. This finding supports that the services under analysis are superior goods, that make up a larger proportion of consumption as income rises.

\footnotetext{
${ }^{16}$ Monthly expenditures are defined as 2.16 times the expenditures observed over two weeks (or, for the small fraction of households that only fill one weekly diary, 4.33 the expenditure observed over one week).

${ }^{17}$ Yearly diary surveys are available since 1990. Two earlier years (1980 and 1981) are also available, but the UCC's in these surveys do not include items of interest such as housekeeping or babysitting services.
} 
Our theoretical model considers the individual as the utility maximizing agent, while in a husband/wife household each member's allocation of time stems from a bargaining process that might result in some degree of specialization. To shed light on the potential differences across family types, we separately calculate budget shares in husband/wife families where only the head works, husband/wife families where both spouses work and other households (most of which are represented by single adult families). Figure 4 reports these figures for 1996. As expected, our model applies better to single-adult families: even if in all family types the budget share of home services increases with the education of the head, differences across educational groups are more marked in singleadult families.

We also use consumption expenditure data to indirectly test the specific micro-level prediction of our model, that is, higher wage rates, by increasing the shadow price of time, should be associated with less hours of home production. To this purpose we study whether consumption of those services that are market substitutes for the output of home production is positively correlated with hourly wages. An issue in implementing this test is that, while the survey provides information on expenditures in a specific and defined period (over two weeks), it does not include information on individual hourly wage rates at a point in time. Hourly wages can only be computed by dividing annual earnings by annual hours (that is, the product of weeks worked and weekly hours), so they depend on the labor supply decision. With this caveat in mind, we calculate the association between the budget share in home services and log hourly wages. Figure 5 plots the fitted values from OLS regressions of the budget share on the head's log hourly wage, in the full working samples for 1996 and 2004. In both years, we find evidence of a statistically significant positive relationship, even if steeper in 1996. Table 4 reports the estimated coefficients, also from regressions separately run for different types of families. In 1996, a ten percent increase in the head's hourly wage is associated with a 0.1 percentage point increase in the budget share of home services in both husband/wife families where the woman does not work (column 2) and in other single-earner families (column 5). While the association between head's hourly wage and budget share is smaller in husband/wife families where the woman does work (column 3), the association is of similar magnitude when evaluated relative to the woman's wage (column 4). This suggests that when the 
woman works, the opportunity cost of home production is more closely tied to her wage than the head's wage.

Finally, we calculate earned income elasticities of the consumption of non-traded goods, by regressing the logarithm of household expenditures in home services on the logarithm of total household income from wages (Table 5). In the full 1996 and 2004 samples, a 1 percent increase in household wage income is associated respectively with a .45 and a .42 percent increase in expenditures in home services (column 1). When calculating income elasticities for households from each fourth of the wage income distribution, we find that they are substantially higher for households in the higher portion of the distribution (columns 2 through 5). When restricting the analysis to an older working sample (the head at least 35 years old) —which should guarantee that current income is a better proxy for permanent income- $-{ }^{18}$ we still find that the elasticity is substantially higher for higher income groups (second panel of Table 5). This finding shows that consumption of home services does not level off beyond a certain earnings threshold, but, on the contrary, it is very responsive to income increases especially for higher income groups. In light of this result, in Section $\mathrm{V}$ we study the association across cities between wage growth at the top of the wage distribution and wage growth at the bottom, and we speculate whether some of the association can be interpreted as the result of the consumption mechanism we put forward in this paper.

\section{Cross-city analysis: The relationship between college share and low- skill employment distribution by sectors}

To this point we have shown that consumers and providers in the market of services that substitute for home production activities tend to belong to different skill groups: consumers are disproportionally high-skill workers, while providers are disproportionally low-skill workers. This finding is consistent with our theoretical framework. We now turn to test its predictions on differences in low-skill employment and wage opportunities across local labor markets. In this section we study the relationship between the share of

\footnotetext{
${ }^{18}$ The less accurately current income proxies for permanent income, the larger is the noise in the estimates of the income elasticities (and so, the larger the downward bias from measurement error). So, we might be worried that some of the differences across income groups arise from current income being a better or worse proxy of permanent income in different groups.
} 
skilled workers in a city and the sector of employment of low-skill workers (Prediction 1). In the next section we focus on the relationship between wage growth at the top and at the bottom of a city's wage distribution (Prediction 5).

To form a panel of cities, we define average measures for workers 16-65 years old residing in Census-defined metropolitan areas in the years 1980, 1990, 2000 and 2005. ${ }^{19}$ Metropolitan Statistical Areas (MSA's) are counties or combinations of counties centering on a substantial urban area. There are between 290 and 300 MSAs in each year. ${ }^{20}$ For unskilled individuals (high-school dropouts, HSD), we define average employment shares in each sector $s$, in a given city $c$ and year $t$, and we estimate the following model:

$$
\text { Emp_Share }{ }^{H S D, s}{ }_{c t}=\alpha+\beta(\text { CollegeShare })_{c t}+\gamma_{t}+\gamma_{c}+\delta X_{c t}+\varepsilon_{c t}
$$

where CollegeShare is the fraction of college graduates in the workforce, ${ }^{21} \gamma_{t}$ and $\gamma_{c}$ are year and city fixed effects, and $X_{c t}$ is a vector of city characteristics that vary over time: the proportion of women, blacks and Hispanics in the total workforce of the city, and the fraction of the unskilled workforce that is foreign-born, aged 16-24, 25-34, 35-44 and 4455. Ordinary Least Square (OLS) estimates of $\beta$ are reported in column 1 of Table 6. In each row the dependent variable is the fraction of the unskilled workforce that is employed in one of the sectors (or occupations) that we have defined in Section III (see table $\mathrm{A} 1$ and $\mathrm{A} 2$ for details).

As the consumption hypothesis predicts (Prediction 1), the presence of more skilled workers in a city is associated with a higher fraction of unskilled workers in home services. It is also associated with a higher employment share in the other sectors that we have coded as non-tradeable, and in education, but with a sharp drop in the employment

${ }^{19}$ The sample is further restricted to wage and salary earners in the civilian labor force who did not live in group quarters. All figures are obtained weighting individual observations by the product between the census frequency weight and a measure of labor supply (weeks worked $\mathrm{x}$ hours usually worked per week).

${ }^{20}$ In some cases the set of counties that make up an area changes over time. Also, as population grows and people migrate to urban areas, new metropolitan areas emerge, so the number of metropolitan areas has increased from 288 in 1980 to 299 in 2005. Even if we do not correct for potential inconsistencies over time, other work suggests that results should not be significantly affected by this issue. For example, in his analysis of the correlation between employment growth and growth in the share of college graduates across MSA's, Shapiro (2006) shows that his results are robust to examining only those areas whose definitions did not change over time.

${ }^{21}$ The average college share across cities and years is 0.24 , with a standard deviation of 0.08 . 
share in traditionally traded sectors (agriculture and manufacturing). When estimating the same associations among the skilled group instead of the unskilled (column 2) we find very different results: college graduates in cities with a higher concentration of workers of their educational level are largely more likely to be employed in financial and business services, somewhat more likely to work in the construction sector and less in public administration. The associations estimated for the "intermediate" skill groups (high school graduates and college dropouts) are in between those estimated for the unskilled and the skilled (lower employment share in traded sectors, higher in education, construction, business and financial services). The marked differences between unskilled and skilled groups are potentially inconsistent with the effects of human capital spillovers. If spillovers mainly arise within sectors, then we would expect cities with a higher share of skilled workers to have a comparative advantage in those sectors where the skilled are more heavily employed, and these should be the sectors where the workforce of any skill tends to concentrate. However, the fact that the unskilled workforce in a skilled city tends to concentrate in different sectors than those where the skilled are employed might be spurious. As already pointed out in Section II, of primary concern is the case when variation in college share across cities is driven by unobserved demand factors. City fixed effects in Equation (1) control for any permanent city specific characteristics (technology or production amenities) that might attract highly educated workers and also directly explain why some sectors are high-skill intensive. However, first-differenced models might still be biased by the presence of time-varying factors (a transitory skilled-biased technological shock) that are correlated with the college share and the employment and industrial structure of a city.

To address this concern, we adopt an instrumental variable strategy that uses the presence of a land grant college in a metropolitan area as a predictor of the share of college educated in it (Moretti, 2004b). Land grant colleges were established in the late $19^{\text {th }}$ century as a result of a movement to provide accessible higher education to people in each U.S. state. Consistent with the intention, the geographic distribution of land-grant universities is quite even. Moretti also reports that the demographic characteristics of metropolitan areas with and without land-grant colleges are similar in most respects. In favor of the relevance of the instrument, we find that in 1980 the average college share in cities with a land-grant school was 26 percent, versus 19 percent in areas without a land- 
grant school. Evidence in favor of the validity of the instrument is provided in Shapiro (2006), who shows that the correlation between human capital distribution and the presence of a land-grant college is essentially zero in the late 1800's, moderate in the early 1900's and the largest between 1940 and 1980. The fact that the correlation arose only after these institutions could have played a significant causal role supports the exogeneity of land-grant status with respect to preexisting differences among metropolitan areas.

We code a binary variable (Land_grant $)$ ) indicating whether a metropolitan area contains a land-grant institution. ${ }^{22}$ We use a full set of interactions between this variable and year dummies as an instrument for CollegeShare cht $_{\text {in }}$ specifications like Equation (1) that do not include city fixed effects. The first-stage estimates for this specification (first panel in Table 6) show that the presence of a land-grant institution raises the share of the workforce who are college graduates by around 4 percentage points in 1980, 5 percentage points in 1990 and 6 percentage points in 2000 and 2005. Columns 3 and 4 report twostep efficient Generalized Method of Moments (GMM) estimates of the coefficient of college share on the employment share in different sectors of high-school dropouts and college graduates, respectively. The GMM estimates confirm Prediction 1: a one-standard deviation ( 8 percentage points) increase in the share of college graduates is associated with one-fourth of a standard deviation (1.6 percentage-point) increase in the fraction of high-school dropouts employed in home services. OLS and GMM estimates are very close in magnitude, and they are both statistically significantly different from zero, even if the latter only at the 10 percent significance level.

As opposed to OLS, GMM estimates the effect of college share on the fraction of high-school dropouts employed in other non-traded activities to be both economically

22 The following MSA's have one or more land-grant colleges (Nevins, 1962): AlbanySchenectady-Troy, NY; Athens, GA; Baton Rouge, LA; Boston, MA; Champaign-UrbanaRantoul, IL; Columbia, MO; Columbia, SC; Columbus, OH; Des Moines, IA; Fargo-Moorhead, ND-MN; Fayetteville-Springdale, AR; Fort Collins-Loveland, CO; Gainesville, FL; GreensboroWinston-Salem-High Pt., NC; Hartford, CT; Honolulu, HI; Knoxville, TN; Lafayette-West Lafayette, IN; Lansing-East Lansing, MI; Lexington-Fayette, KY; Lincoln, NE; Macon-Warner Robins, GA; Madison, WI; Minneapolis-St. Paul, MN-WI; Nashville, TN; Pine Bluff, AR; Portsmouth-Dover-Rochester, NH-ME; Providence, RI; Raleigh-Durham, NC; Reno, NV; Richmond-Petersburg, VA; Riverside-San Bernardino, CA; Sacramento, CA; San Francisco, CA; State College, PA; Tallahassee, FL; Tucson, AZ; Washington, DC-MD-VA and Wilmington, DEMD. 
and statistically insignificant. This result helps us separate the consumption hypothesis we have formulated from the predictions of a model in which employment shifts reflect general spillovers into non-tradeable sectors, simply due to the fact that the higher skilled workers have more income to spend on locally produced non-traded goods.

\section{Cross-city analysis: The relationship between wage growth at the top and at the bottom of the wage distribution}

In the previous section we have established that cities with a higher fraction of skilled individuals in the workforce have a higher share of unskilled workers employed in home services, consistent with a model in which skilled workers, with their high opportunity cost of time, outsource home production activities by buying low-skill intensive services. This framework has also implications for the distribution of wages. In particular, it unveils a mechanism through which rising wage inequality at the top of the distribution might feedback into lower wage inequality at the bottom: where and when wage growth is the highest for high-skilled workers, the demand for home services should increase the most, exerting an upward pressure on the wages of the workers that perform these jobs, who are predominantly low-skilled.

We explore this implication by examining the relationship between relative wage growth at the top of the wage distribution and relative wage growth at the bottom (both with respect to the growth at median) across cities: the larger the share of low-wage earners employed in outsourced home production activities, the larger the association should be. We use data from the 1980, 1990 and 2000 censuses and the 2005 American Community Survey to calculate changes in log real hourly wages $(l w)$ by percentile from 1980 to 1990 , from 1990 to 2000 and from 2000 to $2005 .^{23}$ Earnings growth figures are calculated by city. ${ }^{24}$ Let $Q_{c t}(\tau)$ for $\tau \in(0,1)$ denote the $100 \tau$-quantile of the distribution of $\log$ wages $(l w)$ in city $c$ and year $t$. We calculate earnings growth at percentile $100 \tau$ in city $c$ between $t-1$ and $t\left(\Delta Q_{c t}(\tau)\right)$ by estimating the coefficient $\beta(c, \tau)$ of the following linear quantile specification:

\footnotetext{
${ }^{23}$ Hourly wages are calculated by dividing wage and salary income by annual hours worked (the product between weeks worked and hours usually worked per week). We obtain real wages (in 1989 dollars) using the national level CPI as the deflator.

${ }^{24}$ We restrict the analysis to the 242 MSAs that are defined in the entire period.
} 


$$
\text { Quantile }(l w \mid c, \tau)=\alpha(c, \tau)+\beta(c, \tau) \text { year }_{t}
$$

where year $_{t}$ is an indicator that equals 1 if the observation refers to year $t$, and zero otherwise. Individual hourly wages are weighted by the product of IPUMS frequency weights and the number of hours worked in the previous year.

$$
\text { Let } \Delta \underline{Q}_{c t}=\Delta Q_{c t}(\underline{\tau})-\Delta Q_{c t}(.5) \quad \text { and } \quad \Delta \bar{Q}_{c t}=\Delta Q_{c t}(\bar{\tau})-\Delta Q_{c t}(.5), \quad \text { for } \quad \underline{\tau}<0.5<\bar{\tau} \text {. }
$$

$\Delta \underline{Q}_{c t}$ and $\Delta \bar{Q}_{c t}$ represent respectively changes in log wages at percentiles $\underline{\tau}$ and $\bar{\tau}$ relative to changes in the median log wage.

A positive correlation between $\Delta \underline{Q}_{c t}$ and $\Delta \bar{Q}_{c t}$ is an indication that in cities and years where relative earnings growth has been higher at the top, it has also been higher at the bottom. The consumption hypothesis we want to test for suggests that this positive relationship, if any, should arise where a higher fraction of low-skill workers is employed in home services. We explore this mechanism by specifying a model for $\Delta \underline{Q}_{c t}$ where the effect of $\Delta \bar{Q}_{c t}$ is allowed to vary with the share of low-skill workers employed in home services in city $c$ in a base year (Home_Share H(t-1) $\left._{1}\right)$.

Table 7 reports OLS estimates for the coefficients on $\Delta \bar{Q}_{c t}$, Home_Share $_{c(t-1)}$ and the interaction between these two variables for the case $\underline{\tau}=.15, \bar{\tau}=.85$. Home_Share S(t-1) $_{\text {So }}$ is calculated as the fraction of wage-earners employed in home services among those with hourly wages below the $15^{\text {th }}$ quantile. Employment shares refer to the base year for each period. Home services are identified either on the base of industry (column 2) or occupation (column 3). To ensure that the results are not confounded by differences across cities and over time in the composition of the workforce, we calculate wage growth for hourly wages at different percentiles after the effect of observable personal characteristics is controlled for. This amounts to estimating log wage percentiles from equation (2) augmented for a set of individual characteristics: gender, race (white or else), Hispanic origin, foreign-born status, age (quartic specification) and education (less than a high school degree, high school degree, some college education, college degree).

While the raw correlation between relative wage growth at the top and the bottom of the distribution is found to be positive but not statistically significantly different from 
zero (column 1), when we expand the specification to include the interaction between $\Delta \bar{Q}_{c t}$ and Home_Share ${ }_{c(t-1)}$ (columns 2 and 3), we find the relationship to be strongly positively increasing in the proportion of low-wage workers employed in home services. In particular, in a city where Home_share is equal to .2, a 10 percent increase in the relative wage growth at the $85^{\text {th }}$ percentile with respect to the median is associated with a 4.8 percent increase in the relative wage growth at the $15^{\text {th }}$ percentile with respect to the median. In a city where Home_share is equal to .3, a 10 percent increase in the relative wage growth at the $85^{\text {th }}$ percentile with respect to the median is associated with a 9.2 percent increase in the relative wage growth at the $15^{\text {th }}$ percentile with respect to the median. The magnitude of the estimated association is very similar when employment shares in home services are calculated on the base of a worker's occupation (column 3), while it does not vary with the share of low-wage earners employed in other nontradeable activities (column 4). This last finding suggests that the spillover from skilled workers' consumption to unskilled earnings opportunities does not arise from general "income" effects (that is, simply because skilled workers have higher income to spend on locally produced non-traded goods). It appears that the feedback between wage growth for the skilled and wage growth for the unskilled crucially depends on the size of the sector of outsourced home production activities.

An alternative explanation to the consumption mechanism we are interested in detecting is an association between high-skill and low-skill workers' wage growth that is due to production complementarities or human capital externalities. Column 5 of Table 7 presents a piece of information relevant to distinguish between the two hypotheses. When interacting the top-end relative wage growth with the share of college graduates in the base year, we do not find evidence of a positive relationship between wage growth at the two ends of the distribution.

In our analysis, we study nominal wages, that is wages unadjusted for cost of living. Some of the observed differences in wage levels (and wage growth) across cities, however, are likely to reflect differences in local prices. Under which conditions would differences in the growth of local prices deliver a non-monotone wage growth along the 
earnings distribution? In a setting in which individuals of different skills choose the same consumption bundle, differences in the growth of local prices should not predict a nonmonotone wage growth along the earnings distribution, and so should not contaminate our results. However, our model does allow different skill groups to choose different consumption bundles: in particular, the consumption effects we are interested in detecting arise if skilled workers spend a higher fraction of their budget on the subset of non-traded services that can be thought as substitutes of home production activities. What if, for instance, unskilled workers spend a higher fraction of their budget on housing? ${ }^{25}$ Let's consider, for example, the case of two cities, A and B. In A skilled workers experience a higher relative wage growth than in B, because of a city-specific skilled-biased technological shock. On one hand, our framework predicts that consumption spillovers should be larger in A, and this should exert an upward pressure on the unskilled wage. However, land prices are expected to increase more in A than in B (until the point in which workers are indifferent between living in A or B). So, increases in wages in city A will partially represent an increase in the cost of living. If unskilled workers spend a higher fraction of their budget on housing, then they might experience a higher percent increase in wage rates to compensate for higher land prices. This provides an alternative explanation for differential wage growth at different points of the wage distribution that might confound our hypothesis, but that only arises from assuming perfect mobility of workers of any skill and the existence of one housing market. If unskilled workers are not perfectly mobile (Bound and Holzer, 2002), however, their wages might not fully reflect compensating differentials for housing (or other living) costs. On the other hand, heterogeneity in housing markets might partly shield unskilled workers from incurring the costs associated with living in a "skilled city", but might affect their net return from work through high commuting costs, the more so the more their employment opportunities are represented by non-traded service jobs demanded by skilled workers. All of these elements should be taken into account in order to assess the effects on the welfare of unskilled workers arising from living in skilled (and more expensive) cities, but this is beyond the scope of this paper and is left for future research.

\footnotetext{
${ }^{25}$ Polinsky (1979) estimates that the income elasticity for housing was less than one in the 1970s.
} 


\section{Conclusions}

Census data show that the unskilled workforce in the United States is increasingly concentrated in a sector that can be broadly defined as providing time-intensive services that substitute for home production activities. A standard utility maximization framework predicts that consumption of these services should increase in an individual's opportunity cost of time. Consumer expenditure data show that the fraction of household spending in these services does increase with the head's wage rate. These facts suggest that some of the demand for unskilled work in the United States (and possibly in other developed economies) should be modeled as arising from the demand for outsourced home production activities by skilled workers. We provide two pieces of evidence consistent with this hypothesis. First, we find that at the city level a higher share of skilled individuals in the workforce is associated with a higher fraction of unskilled workers employed in "home services". Second, we find evidence of a positive association between relative wage growth at the top of the wage distribution and relative wage growth at the bottom, whose magnitude is increasing with the fraction of low-wage workers employed in home services. This is consistent with the existence of a feedback between rising wage inequality at the top of the distribution and lower wage inequality at the bottom, which arises from the consumption of outsourced home production services by high-wage workers. This suggests that our framework might contribute to the recent literature on the evolution of wage inequality in the United States: "consumption spillovers" might be a viable explanation, among others, for the recent observed twisting in the wage growth at the bottom of the wage distribution (Autor et al., 2006, 2007).

Our paper is also related to the voluminous literature that examines the causes of citylevel employment and wage growth. In that literature, strong city performance has been linked to various factors, but two hypotheses are most closely related to our work. First, as already pointed out throughout the paper, we face the challenge of separating our consumption hypothesis from the hypothesis of education externalities. Moretti (2004a, $2004 \mathrm{~b}$ and 2004c) examines the claim that having a larger proportion of workers in a city being highly educated benefits uneducated workers by raising their productivity because of spillovers, as well as through imperfect substitution. To the extent that spillovers arise primarily within sectors (which is plausible for technological externalities), we propose to separate this hypothesis from ours by comparing changes in the employment distribution 
across sectors among the unskilled to changes among the skilled. Our hypothesis (that finds support in the data) predicts that, when a city's workforce becomes more skilled, unskilled workers should be more likely to be employed in home services, while the education externality hypothesis predicts that they should be employed in the same sectors where the skilled are.

Second, Beaudry, Green and Sand (2007) show that there are substantial and persistent spillover effects on city-level average wages associated with changes in the fraction of jobs in high paying sectors. Since the effect they measure is not restricted to one educational attainment and is present in almost all industries (and importantly for both tradeable and non-tradeable goods), they conclude that it is consistent with an increase in workers' productivity. This in turn might arise if changes in competitive pressure (through improvements in worker bargaining power) cause a reallocation of employment toward the most efficient firms. Given that those that demand outsourced home production tasks are disproportionally workers in "good jobs", our framework provides a potential explanation for what is driving the spillover effect on unskilled labor markets. Importantly, when evaluating induced changes in the distribution of wages, unskilled labor markets appear to be those most largely affected by the spillover effects from good jobs: Beaudry, Green and Sand (2007) find that cities that experience a change in industrial composition in favor of better paying jobs also experience a decrease in wage inequality that is concentrated in the bottom half of the distribution.

In conclusion, our paper explores (and finds supporting evidence in favor of) an explanation for the employment and wage dynamics of unskilled workers in the United States, which complements (and overlaps with) other explanations provided in the literature, but delivers somewhat different policy implications. We have provided evidence that the earnings prospects of low-skill workers in the United States are dependent on physical proximity to rich workers, because the latter consume timeintensive services that absorb an increasing share of the unskilled workforce. This suggests that regional policies aimed at improving the labor market prospects of the lowskilled in an area should identify high-skill labor, not capital, has the crucial ingredient of regeneration of a local economy. This idea provides a further rationale for policies, such as those on affordable housing, aimed at boosting the socio-economy diversity of local communities. 


\section{References}

Acemoglu, Daron. 2002. “Technical Change, Inequality and the Labor Market.” Journal of Economic Literature, 40, pp. 7-72.

Aguiar, Mark and Erik Hurst. 2007. "Measuring Trends in Leisure: The Allocation Of Time over Five Decades," Quarterly Journal of Economics, forthcoming

Autor David, Frank Levy, and Richard P. Murnane. 2003. "The Skill Content of Recent Technological Change: An Empirical Investigation," Quarterly Journal of Economics, 118(4), pp. 1279-1333.

Autor David, Lawrence F. Katz, and Melissa Schettini Kearney. 2006. "The Polarization of the U.S. Labor Market," American Economic Review Papers and Proceedings, 96(2), pp. 189-194.

Autor David, Lawrence F. Katz, and Melissa Schettini Kearney. 2007. "Trends in U.S. Wage Inequality: Revising the Revisionists," Working paper (March 2007, revised from July 2004).

Beaudry, Paul and David A. Green and Benjamin Sand. 2007. "Spill-overs from Good Jobs.” National Bureau of Economic Research, Working Paper no. 13006.

Baumol, William J. 1967. "Macroeconomics and Unbalanced Growth: The Anatomy of Urban Crisis," American Economic Review, 62, pp. 415-426.

Berman Eli, John Bound and Zvi Griliches, "Changes in the Demand for Skilled Labor within U.S. Manufacturing Industries: Evidence from the Annual Survey of Manufacturing," Quarterly Journal of Economics, pp. 367-397.

Berry, Christopher R. and Edward L. Glaeser. 2005. The Divergence of Human Capital Levels across Cities. Harvard Institute of Economic Research, Discussion Paper $n$. 2091, September 2005.

Borjas, George J. and Rachel M. Friedberg. 2007. “The Immigrant Earnings Turnaround of the 1990s," Unpublished manuscript, April 2007.

Bound, John and Harry Holzer. 2000. "Demand Shifts, Population Adjustments, and Labor Market Outcomes during the 1980s." Journal of labor Economics, 18(10), pp. $20-54$. 
Bound, John and George Johnson. 1992. "Changes in the Structure of Wages During the 1980s: An Evaluation of Alternative Explanations." American Economic Review, 82.

The Bureau of Labor Statistics. 2003. Handbook of Methods, Chapter 16, Consumer Expenditures and Income.

(available at http://www.bls.gov/opub/hom/homtoc pdf.htm)

Card, David. 2001. "Immigrant Inflows, Native Outflows, and the Local Labor Market Impacts of Higher Immigration," Journal of Labor Economics, 19, pp. 22-64

Card, David, and John DiNardo (2002), "Skill Biased Technological Change and Rising Wage Inequality: Some Problems and Puzzles," Journal of Labor Economics, 20(4), pp. 733-783.

Cortes, Patricia. 2006. The Effect of Low-Skilled Immigration on US Prices: Evidence from CPI data. Unpublished manuscript (October 2006).

Dechênes, Olivier. 2006. "Unobserved Ability, Comparative Advantage and the Rising Return to Education in the United States 1979-2002”.

Goos, Maarten and Alan Manning. 2007. "Lousy and Lovely Jobs: the Rising Polarization of Work in Britain." Review of Economics and Statistics, 89(1), pp. 277282.

Gronau, Reuben. 1977. "Leisure, Home Production, and Work--the Theory of the Allocation of Time Revisited." Journal of Political Economy, 85(6), pp. 1099-1124.

Graham, J.W. and Green, C.A. 1984. "Estimating the Parameters of the Household Production Function with Joint Products.” Review of Economics and Statistics, 66(2), pp. $277-282$.

Juhn, Chinhui, Kevin M. Murphy and Brooks Pierce. 1993. "Wage Inequality and the Rise in Returns to Skill.” The Journal of Political Economy. 101(3), pp. 410-442.

Katz, Larry and David Autor. 1999. "Changes in the Wage Structure and Earnings Inequality", in Handbook of Labor Economics, edited by Orley Ashenfelter and David Card. Vol. 3A, Amsterdam, Netherlands, New York, NY, North-Holland, Netherlands: Elsevier.

Katz, Larry and Kevin Murphy. 1992. "Changes in Relative Wages, 1963-1987: Supply and Demand Factors.” Quarterly Journal of Economics, 107, pp. 35-78. 
Kerkhofs, Marcel and Kooreman, Peter. 2003. "Identification and Estimation of a Class of Household Production Models." Journal of Applied Econometrics, 18(3), pp. 337369.

Lemieux, Thomas. 2006a. "Post-secondary Education and Increasing Wage Inequality." American Economic Review Papers and Proceedings, 96(2), pp.195-199.

Lemieux, Thomas. 2006b. "Increasing Residual Wage Inequality: Composition Effects, Noisy Data, or Rising Demand for Skill?” American Economic Review, 96(3), pp. 461-498.

Manning, Alan. 2004. "We Can Work It Out: The Impact of Technological Change on the Demand for Low-Skill Workers." Scottish Journal of Political Economy, 51(5), pp. 581-608.

Mincer, Jacob. 1997. "Changes in Wage Inequality, 1970-1990." Research in Labor Economics, 16, pp. 1-18.

Moretti, Enrico. 2004a. "Human Capital Externalities in Cities," in Handbook of Urban and Regional Economics, V. Henderson and J.F. Thisse (eds.), North HollandElsevier.

Moretti, Enrico. 2004b. "Estimating the Social Return to Higher Education; Evidence from Longitudinal and Repeated Cross-sectional Data." Journal of Econometrics, 121, pp. 175-212.

Moretti, Enrico. 2004c. "Workers' Education, Spillovers and Productivity: Evidence from Plant-Level Production Functions." American Economic Review, 94(3).

Nevins, Allan. 1962. The State Universities and Democracy. Urbana, University of Illinois Press.

Piketty, Thomas and Saez, Emmanuel. 2003. Income Inequality in the United States, 1913-98.” Quarterly Journal of Economics, 118(1), pp.1-39.

Ruggles, S., M. Sobek, T. Alexander, C. A. Fitch, R. Goeken, P. K. Hall, M. King, and C. Ronnander. 2004. "Integrated Public Use Microdata Series: Version 3.0." Minneapolis, MN: Minnesota Population Center.

Shapiro, Jesse M. 2006. "Smart Cities: Quality of Life, Productivity, and the Growth Effects of Human Capital." Review of Economics and Statistics, 88(2), pp. 324-335. 
Table 1

Employment shares in different sectors by education and year, 1980-2005

\begin{tabular}{|c|c|c|c|c|c|}
\hline & 1980 & 1990 & 2000 & 2005 & 1980-2005 Change \\
\hline \multicolumn{6}{|l|}{ High-school drop-outs } \\
\hline Non-trade industries & 0.33 & 0.40 & 0.42 & 0.42 & 0.09 \\
\hline Home services & 0.15 & 0.20 & 0.23 & 0.24 & 0.09 \\
\hline Other non-trade industries & 0.18 & 0.20 & 0.19 & 0.18 & 0.00 \\
\hline Agriculture, Mining, Manufacturing & 0.37 & 0.29 & 0.24 & 0.22 & -0.14 \\
\hline Construction & 0.08 & 0.10 & 0.14 & 0.18 & 0.10 \\
\hline Wholesale t., Transportation, Utilities & 0.12 & 0.11 & 0.10 & 0.10 & -0.02 \\
\hline Financial Services & 0.03 & 0.03 & 0.03 & 0.02 & 0.00 \\
\hline Business Services & 0.01 & 0.02 & 0.03 & 0.02 & 0.01 \\
\hline Public Administration & 0.03 & 0.02 & 0.01 & 0.01 & -0.02 \\
\hline Education & 0.03 & 0.03 & 0.02 & 0.02 & -0.01 \\
\hline Home service occupations & 0.18 & 0.21 & 0.23 & 0.26 & 0.08 \\
\hline Other non-traded occupations & 0.16 & 0.18 & 0.17 & 0.16 & 0.00 \\
\hline \multicolumn{6}{|l|}{ High-school graduates } \\
\hline$\overline{\text { Non-trade industries }}$ & 0.30 & 0.35 & 0.38 & 0.40 & 0.10 \\
\hline Home services & 0.10 & 0.13 & 0.15 & 0.17 & 0.07 \\
\hline Other non-trade industries & 0.20 & 0.22 & 0.23 & 0.24 & 0.03 \\
\hline Agriculture, Mining, Manufacturing & 0.29 & 0.24 & 0.21 & 0.17 & -0.12 \\
\hline Construction & 0.07 & 0.08 & 0.10 & 0.12 & 0.05 \\
\hline Wholesale t., Transportation, Utilities & 0.15 & 0.15 & 0.14 & 0.13 & -0.02 \\
\hline Financial Services & 0.07 & 0.07 & 0.06 & 0.06 & -0.01 \\
\hline Business Services & 0.03 & 0.04 & 0.04 & 0.04 & 0.01 \\
\hline Public Administration & 0.06 & 0.04 & 0.04 & 0.04 & -0.02 \\
\hline Education & 0.03 & 0.03 & 0.03 & 0.03 & 0.00 \\
\hline Home service occupations & 0.10 & 0.12 & 0.14 & 0.16 & 0.07 \\
\hline Other non-traded occupations & 0.16 & 0.19 & 0.18 & 0.20 & 0.04 \\
\hline \multicolumn{6}{|l|}{ Some college } \\
\hline Non-trade industries & 0.32 & 0.34 & 0.37 & 0.40 & 0.08 \\
\hline Home services & 0.09 & 0.11 & 0.12 & 0.13 & 0.04 \\
\hline Other non-trade industries & 0.23 & 0.24 & 0.25 & 0.27 & 0.03 \\
\hline Agriculture, Mining, Manufacturing & 0.22 & 0.19 & 0.15 & 0.13 & -0.09 \\
\hline Construction & 0.05 & 0.06 & 0.06 & 0.07 & 0.02 \\
\hline Wholesale t., Transportation, Utilities & 0.15 & 0.15 & 0.14 & 0.13 & -0.02 \\
\hline Financial Services & 0.09 & 0.09 & 0.09 & 0.09 & 0.00 \\
\hline Business Services & 0.05 & 0.07 & 0.08 & 0.08 & 0.02 \\
\hline Public Administration & 0.08 & 0.07 & 0.06 & 0.07 & -0.01 \\
\hline Education & 0.04 & 0.04 & 0.04 & 0.04 & 0.00 \\
\hline Home service occupations & 0.09 & 0.09 & 0.11 & 0.12 & 0.04 \\
\hline Other non-traded occupations & 0.17 & 0.19 & 0.18 & 0.19 & 0.02 \\
\hline
\end{tabular}




\begin{tabular}{llllll} 
College graduates & & & & & \\
\hline Non-trade industries & 0.24 & 0.26 & 0.27 & 0.28 & 0.04 \\
$\quad$ Home services & $\mathbf{0 . 0 4}$ & $\mathbf{0 . 0 5}$ & $\mathbf{0 . 0 5}$ & $\mathbf{0 . 0 6}$ & $\mathbf{0 . 0 2}$ \\
$\quad$ Other non-trade industries & 0.20 & 0.21 & 0.22 & 0.22 & 0.02 \\
Agriculture, Mining, Manufacturing & 0.18 & 0.16 & 0.13 & 0.12 & -0.06 \\
Construction & 0.03 & 0.03 & 0.02 & 0.03 & 0.00 \\
Wholesale t., Transportation, Utilities & 0.09 & 0.10 & 0.09 & 0.09 & 0.00 \\
Financial Services & 0.09 & 0.10 & 0.10 & 0.11 & 0.02 \\
Business Services & 0.10 & 0.13 & 0.16 & 0.16 & 0.05 \\
Public Administration & 0.08 & 0.06 & 0.06 & 0.06 & -0.01 \\
Education & 0.19 & 0.16 & 0.16 & 0.16 & -0.04 \\
& & & & & \\
Home service occupations & $\mathbf{0 . 0 3}$ & $\mathbf{0 . 0 3}$ & $\mathbf{0 . 0 4}$ & $\mathbf{0 . 0 4}$ & $\mathbf{0 . 0 2}$ \\
Other non-traded occupations & 0.11 & 0.13 & 0.12 & 0.13 & 0.01
\end{tabular}

\footnotetext{
Notes: For each educational group, the first ten rows report the share of the workforce employed in each group of industries (exhaustive categories). The home service sub-industries include the threedigit sectors: eating and drinking places, services to buildings, detective and protective services, automotive rental and leasing, taxi and limousine service, other repair services, personal services, entertainment services, child care services. The last two rows report the share of the workforce employed in two groups of non-traded occupations. Home service occupations include private household, protective service, food preparation and service and personal service occupations. For a detailed mapping of industry or occupation codes into the above categories, see Tables A1-A2.

Sample restricted to individuals aged 16 through 65 who were employed in the civilian labor force at the time of the survey, were not unpaid family workers, who did not live in group quarters and who resided in a Metropolitan Statistical Area (MSA).

Figures are weighted by the product of IPUMS weights and a measure of annual labor supply.

Source: IPUMS extracts from 1980-1990-2000 censuses and 2005 American Community Survey file.
} 
Table 2

Employment shares in different sectors by wage percentile and year, 1980-2005

\begin{tabular}{|c|c|c|c|c|c|c|c|c|}
\hline & 1980 & 1990 & 2000 & 2005 & 1980 & 1990 & 2000 & 2005 \\
\hline Wage percentiles & \multicolumn{4}{|c|}{ Below 10} & \multicolumn{4}{|c|}{ Between 10 and 20} \\
\hline Non-trade industries & 0.50 & 0.58 & 0.57 & 0.60 & 0.48 & 0.50 & 0.52 & 0.53 \\
\hline Home services & 0.23 & 0.28 & 0.29 & 0.31 & 0.18 & 0.20 & 0.22 & 0.23 \\
\hline Other non-trade & 0.27 & 0.30 & 0.28 & 0.29 & 0.30 & 0.30 & 0.30 & 0.30 \\
\hline Trade industries & 0.20 & 0.15 & 0.14 & 0.12 & 0.21 & 0.18 & 0.15 & 0.14 \\
\hline Construction & 0.04 & 0.04 & 0.05 & 0.06 & 0.03 & 0.05 & 0.06 & 0.08 \\
\hline Wholesale trade et al. & 0.07 & 0.07 & 0.07 & 0.07 & 0.07 & 0.09 & 0.09 & 0.08 \\
\hline Financial Services & 0.05 & 0.05 & 0.04 & 0.04 & 0.07 & 0.07 & 0.05 & 0.04 \\
\hline Business Services & 0.03 & 0.04 & 0.05 & 0.04 & 0.03 & 0.04 & 0.05 & 0.04 \\
\hline Public Administration & 0.03 & 0.02 & 0.02 & 0.02 & 0.03 & 0.03 & 0.02 & 0.02 \\
\hline Education & 0.07 & 0.06 & 0.07 & 0.06 & 0.07 & 0.06 & 0.07 & 0.06 \\
\hline Wage percentiles & \multicolumn{4}{|c|}{ Between 20 and 30} & \multicolumn{4}{|c|}{ Between 30 and 40} \\
\hline Non-trade industries & 0.41 & 0.43 & 0.45 & 0.46 & 0.34 & 0.37 & 0.40 & 0.41 \\
\hline Home services & 0.12 & 0.14 & 0.16 & 0.17 & 0.09 & 0.11 & 0.13 & 0.12 \\
\hline Other non-trade & 0.28 & 0.29 & 0.29 & 0.30 & 0.25 & 0.26 & 0.27 & 0.29 \\
\hline Trade industries & 0.22 & 0.18 & 0.16 & 0.14 & 0.24 & 0.19 & 0.17 & 0.15 \\
\hline Construction & 0.04 & 0.05 & 0.06 & 0.08 & 0.04 & 0.05 & 0.06 & 0.08 \\
\hline Wholesale trade et al. & 0.09 & 0.10 & 0.10 & 0.10 & 0.10 & 0.11 & 0.12 & 0.11 \\
\hline Financial Services & 0.10 & 0.09 & 0.07 & 0.06 & 0.09 & 0.09 & 0.08 & 0.08 \\
\hline Business Services & 0.04 & 0.05 & 0.05 & 0.05 & 0.04 & 0.05 & 0.06 & 0.06 \\
\hline Public Administration & 0.05 & 0.04 & 0.03 & 0.03 & 0.06 & 0.05 & 0.05 & 0.05 \\
\hline Education & 0.06 & 0.06 & 0.07 & 0.07 & 0.07 & 0.06 & 0.08 & 0.08 \\
\hline Wage percentiles & \multicolumn{4}{|c|}{ Between 40 and 50} & \multicolumn{4}{|c|}{ Between 50 and 60} \\
\hline Non-trade industries & 0.30 & 0.32 & 0.35 & 0.36 & 0.27 & 0.28 & 0.31 & 0.31 \\
\hline Home services & 0.07 & 0.08 & 0.10 & 0.10 & 0.06 & 0.07 & 0.08 & 0.08 \\
\hline Other non-trade & 0.23 & 0.24 & 0.25 & 0.26 & 0.21 & 0.22 & 0.23 & 0.23 \\
\hline Trade industries & 0.26 & 0.21 & 0.17 & 0.15 & 0.28 & 0.22 & 0.18 & 0.16 \\
\hline Construction & 0.05 & 0.06 & 0.06 & 0.07 & 0.05 & 0.06 & 0.07 & 0.07 \\
\hline Wholesale trade et al. & 0.12 & 0.12 & 0.13 & 0.12 & 0.13 & 0.14 & 0.14 & 0.14 \\
\hline Financial Services & 0.08 & 0.09 & 0.09 & 0.08 & 0.07 & 0.09 & 0.08 & 0.09 \\
\hline Business Services & 0.05 & 0.06 & 0.07 & 0.06 & 0.04 & 0.06 & 0.08 & 0.07 \\
\hline Public Administration & 0.08 & 0.07 & 0.06 & 0.06 & 0.08 & 0.07 & 0.07 & 0.07 \\
\hline Education & 0.07 & 0.07 & 0.08 & 0.09 & 0.08 & 0.08 & 0.09 & 0.09 \\
\hline
\end{tabular}




\begin{tabular}{|c|c|c|c|c|c|c|c|c|}
\hline Wage percentiles & \multicolumn{4}{|c|}{ Between 60 and 70} & \multicolumn{4}{|c|}{ Between 70 and 80} \\
\hline Non-trade industries & 0.22 & 0.24 & 0.27 & 0.27 & 0.17 & 0.21 & 0.24 & 0.24 \\
\hline Home services & 0.04 & 0.05 & 0.06 & 0.06 & 0.03 & 0.04 & 0.05 & 0.04 \\
\hline Other non-trade & 0.18 & 0.19 & 0.21 & 0.21 & 0.14 & 0.18 & 0.19 & 0.20 \\
\hline Trade industries & 0.31 & 0.23 & 0.18 & 0.15 & 0.33 & 0.25 & 0.20 & 0.16 \\
\hline Construction & 0.05 & 0.06 & 0.06 & 0.07 & 0.05 & 0.06 & 0.06 & 0.07 \\
\hline Wholesale trade et al. & 0.16 & 0.17 & 0.16 & 0.15 & 0.21 & 0.18 & 0.15 & 0.14 \\
\hline Financial Services & 0.06 & 0.08 & 0.08 & 0.08 & 0.05 & 0.07 & 0.08 & 0.09 \\
\hline Business Services & 0.04 & 0.07 & 0.09 & 0.09 & 0.04 & 0.07 & 0.10 & 0.10 \\
\hline Public Administration & 0.08 & 0.07 & 0.07 & 0.08 & 0.08 & 0.08 & 0.08 & 0.09 \\
\hline Education & 0.07 & 0.08 & 0.09 & 0.11 & 0.07 & 0.08 & 0.10 & 0.10 \\
\hline Wage percentiles & \multicolumn{4}{|c|}{ Between 80 and 90} & \multicolumn{4}{|c|}{ Above 90} \\
\hline Non-trade industries & 0.12 & 0.18 & 0.21 & 0.21 & 0.13 & 0.16 & 0.20 & 0.21 \\
\hline Home services & 0.02 & 0.03 & 0.03 & 0.03 & 0.03 & 0.03 & 0.03 & $\mathbf{0 . 0 3}$ \\
\hline Other non-trade & 0.10 & 0.15 & 0.17 & 0.18 & 0.10 & 0.13 & 0.17 & 0.18 \\
\hline Trade industries & 0.34 & 0.26 & 0.21 & 0.18 & 0.32 & 0.25 & 0.20 & 0.19 \\
\hline Construction & 0.07 & 0.06 & 0.06 & 0.05 & 0.07 & 0.06 & 0.04 & 0.04 \\
\hline Wholesale trade et al. & 0.20 & 0.17 & 0.13 & 0.13 & 0.16 & 0.15 & 0.13 & 0.12 \\
\hline Financial Services & 0.05 & 0.07 & 0.08 & 0.09 & 0.08 & 0.12 & 0.12 & 0.15 \\
\hline Business Services & 0.04 & 0.07 & 0.12 & 0.13 & 0.07 & 0.11 & 0.16 & 0.17 \\
\hline Public Administration & 0.08 & 0.08 & 0.09 & 0.10 & 0.08 & 0.06 & 0.06 & 0.07 \\
\hline Education & 0.09 & 0.10 & 0.10 & 0.11 & 0.09 & 0.10 & 0.08 & 0.07 \\
\hline
\end{tabular}

Notes: For each educational group, the first ten rows report the share of the workforce employed in each group of industries (exhaustive categories). The home service sub-industries include the threedigit sectors: eating and drinking places, services to buildings, detective and protective services, automotive rental and leasing, taxi and limousine service, other repair services, personal services, entertainment services, child care services. Traded industries include agriculture, mining and manufacturing. Wholesale trade et al. include transportation and utilities. For the detailed mapping of three-digit industry codes into the above categories, see Tables A1.

Sample restricted to individuals aged 16 through 65 who were employed in the civilian labor force at the time of the survey, were not unpaid family workers, who did not live in group quarters and who resided in a Metropolitan Statistical Area (MSA). Earnings percentiles based on hourly wages, defined as annual wages divided by annual labor supply (the product between number of weeks worked and usual number of hours worked per week).

Figures are weighted by the product of IPUMS weights and annual labor supply.

Source: IPUMS extracts from 1980-1990-2000 censuses and 2005 American Community Survey file. 
Table 3

Hourly wages (in \$1989) by educational level and sector of employment, 1980-2005

\begin{tabular}{|c|c|c|c|c|c|c|c|}
\hline \multirow[b]{2}{*}{ High school dropouts } & \multirow[b]{2}{*}{$\begin{array}{l}\text { Las a fraction } \\
\text { of the workforc }\end{array}$} & \multirow{2}{*}{$\begin{array}{l}1980 \\
{[0.19} \\
e]\end{array}$} & \multirow{2}{*}{$\begin{array}{l}1990 \\
0.13\end{array}$} & \multirow{2}{*}{$\begin{array}{l}\mathbf{2 0 0 0} \\
0.11\end{array}$} & \multirow{2}{*}{$\begin{array}{l}\mathbf{2 0 0 5} \\
0.10]\end{array}$} & \multicolumn{2}{|c|}{ NT/TR wage gap } \\
\hline & & & & & & 1980 & 2005 \\
\hline \multirow[t]{4}{*}{ Home services } & mean & 6.98 & 6.57 & 6.70 & 6.30 & 0.66 & 0.75 \\
\hline & median & 5.71 & 5.29 & 5.34 & 5.17 & 0.63 & 0.73 \\
\hline & 10th percentile & 2.47 & 2.75 & 2.78 & 2.69 & 0.58 & 0.75 \\
\hline & 90th percentile & 12.34 & 11.34 & 11.11 & 10.62 & 0.68 & 0.74 \\
\hline \multirow[t]{4}{*}{ Other sectors } & mean & 10.63 & 9.20 & 8.72 & 8.43 & & \\
\hline & median & 9.11 & 7.80 & 7.12 & 7.05 & & \\
\hline & 10th percentile & 4.28 & 3.76 & 3.57 & 3.60 & & \\
\hline & 90th percentile & 18.09 & 15.99 & 14.57 & 14.37 & & \\
\hline \multicolumn{8}{|l|}{ High school graduates } \\
\hline \multirow[t]{4}{*}{ Home services } & mean & 8.17 & 7.77 & 8.01 & 7.70 & 0.70 & 0.71 \\
\hline & median & 6.85 & 6.41 & 6.72 & 6.46 & 0.67 & 0.69 \\
\hline & 10th percentile & 3.36 & 3.27 & 3.44 & 3.23 & 0.64 & 0.70 \\
\hline & 90th percentile & 13.97 & 13.46 & 13.38 & 12.93 & 0.73 & 0.73 \\
\hline \multirow[t]{4}{*}{ Other sectors } & mean & 11.62 & 10.77 & 10.73 & 10.78 & & \\
\hline & median & 10.21 & 9.62 & 9.25 & 9.37 & & \\
\hline & 10th percentile & 5.26 & 4.81 & 4.73 & 4.61 & & \\
\hline & 90th percentile & 19.24 & 17.93 & 17.79 & 17.78 & & \\
\hline \multicolumn{8}{|l|}{ Some college } \\
\hline \multirow[t]{4}{*}{ Home services } & mean & 8.65 & 8.74 & 9.08 & 8.89 & 0.69 & 0.68 \\
\hline & median & 7.27 & 7.21 & 7.45 & 7.39 & 0.67 & 0.65 \\
\hline & 10th percentile & 3.39 & 3.47 & 3.70 & 3.45 & 0.62 & 0.64 \\
\hline & 90th percentile & 14.80 & 15.00 & 15.10 & 15.28 & 0.72 & 0.71 \\
\hline \multirow[t]{4}{*}{ Other sectors } & mean & 12.48 & 12.34 & 12.53 & 13.04 & & \\
\hline & median & 10.90 & 10.87 & 10.67 & 11.30 & & \\
\hline & 10th percentile & 5.45 & 5.29 & 5.34 & 5.36 & & \\
\hline & 90th percentile & 20.56 & 20.19 & 20.56 & 21.66 & & \\
\hline \multicolumn{8}{|l|}{ College graduates } \\
\hline \multirow[t]{4}{*}{ Home services } & mean & 12.25 & 12.57 & 13.53 & 13.50 & 0.70 & 0.64 \\
\hline & median & 9.41 & 9.71 & 10.30 & 10.06 & 0.62 & 0.59 \\
\hline & 10th percentile & 4.51 & 4.55 & 4.80 & 4.36 & 0.62 & 0.55 \\
\hline & 90th percentile & 21.93 & 22.44 & 24.55 & 25.21 & 0.76 & 0.61 \\
\hline \multirow[t]{4}{*}{ Other sectors } & mean & 17.51 & 18.23 & 19.87 & 21.24 & & \\
\hline & median & 15.10 & 15.38 & 15.81 & 16.94 & & \\
\hline & 10th percentile & 7.24 & 7.37 & 7.50 & 7.94 & & \\
\hline & 90th percentile & 28.94 & 30.29 & 33.02 & 41.37 & & \\
\hline
\end{tabular}

Note: Sample restricted to individuals employed for salary 16-65 years old residing in an MSA. "Home Services": services that can be thought as substitutes of home production (see Table A1). Figures are weighted. The first row below the heading reports the proportion of the workforce without a high school degree in each year. The last two columns report the ratio between hourly wages paid in home services and other sectors in 1980 and 2005. Source: IPUMS extracts from 1980-1990-2000 censuses and 2005 American Community Survey file. 
Table 4

Correlation between hourly wages and budget share of services that are substitutes for home production; CEX Diary Surveys 1996 and 2004

\begin{tabular}{|c|c|c|c|c|c|}
\hline \multirow[t]{3}{*}{1996} & \multirow{3}{*}{$\begin{array}{l}\text { All families } \\
\text { (1) }\end{array}$} & \multicolumn{3}{|c|}{ Husband/Wife Families } & \multirow{3}{*}{$\begin{array}{l}\text { Other Families } \\
\text { (5) }\end{array}$} \\
\hline & & \multirow{2}{*}{$\begin{array}{l}\text { Woman does } \\
\text { NOT work } \\
(2)\end{array}$} & \multicolumn{2}{|c|}{ Woman works } & \\
\hline & & & (3) & $(4)$ & \\
\hline $\begin{array}{l}\text { Head's log } \\
\text { hourly wage }\end{array}$ & $\begin{array}{l}0.006^{* *} \\
(0.003)\end{array}$ & $\begin{array}{c}0.010^{*} \\
(0.006)\end{array}$ & $\begin{array}{c}0.007 * \\
(0.004)\end{array}$ & $\begin{array}{c}0.007 \\
(0.005)\end{array}$ & $\begin{array}{l}0.012 * * \\
(0.005)\end{array}$ \\
\hline $\begin{array}{l}\text { Wife's log } \\
\text { hourly wage }\end{array}$ & & & & $\begin{array}{l}0.013 * * * \\
(0.004)\end{array}$ & \\
\hline Constant & $\begin{array}{l}0.110^{* * * *} \\
(0.008)\end{array}$ & $\begin{array}{l}0.071 * * * \\
(0.016)\end{array}$ & $\begin{array}{l}0.103^{* * *} \\
(0.012)\end{array}$ & $\begin{array}{l}0.075^{* * *} \\
(0.016)\end{array}$ & $\begin{array}{l}0.110^{* * *} \\
(0.013)\end{array}$ \\
\hline Observations & 2,976 & 372 & 1,345 & 1,188 & 1,259 \\
\hline \multirow[t]{3}{*}{2004} & All families & \multicolumn{3}{|c|}{ Husband/Wife Families } & Other Families \\
\hline & & $\begin{array}{l}\text { Woman does } \\
\text { NOT work }\end{array}$ & Wo & works & \\
\hline & (1) & $(2)$ & (3) & (4) & $(5)$ \\
\hline $\begin{array}{l}\text { Head's log } \\
\text { hourly wage }\end{array}$ & $\begin{array}{l}0.006 * * \\
(0.002)\end{array}$ & $\begin{array}{l}0.027 * * * \\
(0.006)\end{array}$ & $\begin{array}{c}0.006 \\
(0.004)\end{array}$ & $\begin{array}{c}0.004 \\
(0.004)\end{array}$ & $\begin{array}{c}0.008^{*} \\
(0.004)\end{array}$ \\
\hline $\begin{array}{l}\text { Wife's log } \\
\text { hourly wage }\end{array}$ & & & & $\begin{array}{c}0.006^{*} \\
(0.003)\end{array}$ & \\
\hline Constant & $\begin{array}{l}0.121^{* * *} \\
(0.007)\end{array}$ & $\begin{array}{c}0.037^{*} \\
(0.019)\end{array}$ & $\begin{array}{l}0.111^{* * *} \\
(0.011)\end{array}$ & $\begin{array}{l}0.100^{* * *} \\
(0.012)\end{array}$ & $\begin{array}{l}0.133^{* * *} \\
(0.011)\end{array}$ \\
\hline Observations & 5,116 & 773 & 2,133 & 2,068 & 2,210 \\
\hline
\end{tabular}

Note: Sample restricted to household headed by individuals at least 18 and no more than 65 who worked for salary in the 12 months before the interview. The family head is conventionally fixed to be the male in all husband/wife families. "Other families" in column 5 include single-adult families (73\% and 72\% in 1996 and 2004) and other mixed families (27\% and 28\% in 1996 and 2004).

Source: 1996 and 2004 CEX Diary Surveys. 
Table 5

Earned Income Elasticities of Consumption of services that are substitutes for home production; CEX Diary Surveys 1996 and 2004

\begin{tabular}{|c|c|c|c|c|c|}
\hline \multirow[t]{2}{*}{1996} & \multirow[t]{2}{*}{ All families } & \multicolumn{4}{|c|}{ Family Wage Income } \\
\hline & & $\begin{array}{l}\text { Below } 25^{\text {th }} \\
\text { percentile }\end{array}$ & $\begin{array}{l}\text { Between } 25^{\text {th }}- \\
50^{\text {th }} \text { percentile }\end{array}$ & $\begin{array}{l}\text { Between } 50^{\text {th }}- \\
75^{\text {th }} \text { percentile }\end{array}$ & $\begin{array}{l}\text { Above } 75^{\text {th }} \\
\text { percentile }\end{array}$ \\
\hline & $(1)$ & $(2)$ & $(3)$ & $(4)$ & $(5)$ \\
\hline Log Household & $0.425 * * *$ & $0.176^{* * *}$ & $0.864 * * *$ & $0.462 *$ & $0.814 * * *$ \\
\hline Wage Income & $(0.020)$ & $(0.040)$ & $(0.274)$ & $(0.251)$ & $(0.105)$ \\
\hline \multirow[t]{2}{*}{ Constant } & $0.634 * * *$ & $2.901 * * *$ & -4.093 & 0.243 & $-3.603 * * *$ \\
\hline & $(0.208)$ & $(0.369)$ & $(2.818)$ & $(2.703)$ & $(1.200)$ \\
\hline Observations & 2,739 & 619 & 668 & 733 & 719 \\
\hline \multicolumn{6}{|l|}{ Head 35+ } \\
\hline Log Household & $0.435 * * *$ & $0.100 * *$ & $1.197 * * *$ & $0.844 * *$ & $0.797 * * *$ \\
\hline Wage Income & $(0.026)$ & $(0.051)$ & $(0.361)$ & $(0.349)$ & $(0.125)$ \\
\hline \multirow[t]{2}{*}{ Constant } & $0.568 * *$ & $3.623 * * *$ & $-7.548 * *$ & -3.894 & $-3.389 * *$ \\
\hline & $(0.279)$ & $(0.478)$ & $(3.762)$ & $(3.808)$ & $(1.441)$ \\
\hline Observations & 1,753 & 399 & 444 & 430 & 480 \\
\hline \multirow[t]{4}{*}{2004} & \multirow[t]{3}{*}{ All families } & \multicolumn{4}{|c|}{ Family Wage Income } \\
\hline & & Below $25^{\text {th }}$ & Between $25^{\text {th }}$ - & Between $50^{\text {th }}-$ & Above $75^{\text {th }}$ \\
\hline & & percentile & $50^{\text {th }}$ percentile & $75^{\text {th }}$ percentile & percentile \\
\hline & $(1)$ & $(2)$ & $(3)$ & $(4)$ & $(5)$ \\
\hline Log Household & $0.451 * * *$ & $0.084 * *$ & $1.102 * * *$ & $1.233 * * *$ & $0.880 * * *$ \\
\hline Wage Income & $(0.017)$ & $(0.037)$ & $(0.218)$ & $(0.207)$ & $(0.103)$ \\
\hline \multirow[t]{2}{*}{ Constant } & $0.469 * *$ & $3.869 * * *$ & $-6.528 * * *$ & $-8.201 * * *$ & $-4.379 * * *$ \\
\hline & $(0.183)$ & $(0.350)$ & $(2.297)$ & $(2.285)$ & $(1.203)$ \\
\hline Observations & 4,703 & 1,032 & 1,151 & 1,236 & 1,284 \\
\hline \multicolumn{6}{|l|}{ Head 35+ } \\
\hline Log Household & $0.536 * * *$ & 0.072 & 0.429 & $0.707 * * *$ & $1.000 * * *$ \\
\hline Wage Income & $(0.024)$ & $(0.057)$ & $(0.281)$ & $(0.258)$ & $(0.134)$ \\
\hline \multirow[t]{2}{*}{ Constant } & $-0.473 *$ & $4.016 * * *$ & 0.560 & -2.357 & $-5.795 * * *$ \\
\hline & $(0.264)$ & $(0.560)$ & $(3.008)$ & $(2.877)$ & $(1.582)$ \\
\hline Observations & 3,310 & 759 & 788 & 870 & 893 \\
\hline
\end{tabular}

Note: Sample restricted to household headed by individuals at least 18 and no more than 65 . The family head is conventionally fixed to be the male in all husband/wife families.

Source: 1996 and 2004 CEX Diary Surveys. 
Table 6

The effect of the share of college graduates on the structure of employment, 1980-2005

\begin{tabular}{|c|c|c|c|c|}
\hline $\begin{array}{l}\text { Education Group } \\
\text { Estimation method }\end{array}$ & $\begin{array}{l}\text { High-School } \\
\text { Dropouts } \\
\text { OLS } \\
(1)\end{array}$ & $\begin{array}{l}\text { College } \\
\text { Graduates } \\
\text { OLS } \\
(2)\end{array}$ & $\begin{array}{l}\text { High-School } \\
\text { Dropouts } \\
\text { IV } \\
(3)\end{array}$ & $\begin{array}{l}\text { College } \\
\text { Graduates } \\
\text { IV } \\
\text { (4) }\end{array}$ \\
\hline \multicolumn{5}{|l|}{ Sectors } \\
\hline Home services & $\begin{array}{l}0.248 * * * \\
(0.093)\end{array}$ & $\begin{array}{l}0.035 \\
(0.033)\end{array}$ & $\begin{array}{l}0.202^{*} \\
(0.119)\end{array}$ & $\begin{array}{l}-0.013 \\
(0.042)\end{array}$ \\
\hline Other non-traded & $\begin{array}{l}0.242 * * * \\
(0.089)\end{array}$ & $\begin{array}{l}-0.121^{*} \\
(0.070)\end{array}$ & $\begin{array}{l}0.068 \\
(0.086)\end{array}$ & $\begin{array}{l}-0.318^{* * *} \\
(0.084)\end{array}$ \\
\hline Traded & $\begin{array}{l}-0.548^{* * * *} \\
(0.127)\end{array}$ & $\begin{array}{l}-0.100 \\
(0.073)\end{array}$ & $\begin{array}{l}-0.813 * * * \\
(0.164)\end{array}$ & $\begin{array}{l}-0.581 * * * \\
(0.120)\end{array}$ \\
\hline Construction & $\begin{array}{l}-0.069 \\
(0.092)\end{array}$ & $\begin{array}{l}0.056^{* *} \\
(0.027)\end{array}$ & $\begin{array}{l}0.291 * * * \\
(0.028)\end{array}$ & $\begin{array}{l}-0.029 \\
(0.022)\end{array}$ \\
\hline Wholesale/Transport/ & -0.012 & 0.026 & -0.020 & $-0.215 * * *$ \\
\hline Utilities & $(0.074)$ & $(0.051)$ & $(0.066)$ & $(0.054)$ \\
\hline Financial Services & $\begin{array}{l}0.016 \\
(0.029)\end{array}$ & $\begin{array}{l}0.112^{* *} \\
(0.054)\end{array}$ & $\begin{array}{l}0.086^{* *} \\
(0.037)\end{array}$ & $\begin{array}{l}0.059 \\
(0.090)\end{array}$ \\
\hline Business Services & $\begin{array}{l}0.014 \\
(0.035)\end{array}$ & $\begin{array}{l}0.195 * * * \\
(0.053)\end{array}$ & $\begin{array}{l}-0.081 * * \\
(0.030)\end{array}$ & $\begin{array}{l}0.196 * * * \\
(0.064)\end{array}$ \\
\hline Public Administration & $\begin{array}{l}0.032 \\
(0.038)\end{array}$ & $\begin{array}{l}-0.116^{* *} \\
(0.050)\end{array}$ & $\begin{array}{l}-0.058 \\
(0.039)\end{array}$ & $\begin{array}{l}0.472 * * * \\
(0.113)\end{array}$ \\
\hline Education & $\begin{array}{l}0.078^{*} \\
(0.040)\end{array}$ & $\begin{array}{l}-0.048 \\
(0.075)\end{array}$ & $\begin{array}{l}0.121 * * * \\
(0.037)\end{array}$ & $\begin{array}{l}0.344^{* *} \\
(0.165)\end{array}$ \\
\hline \multicolumn{5}{|l|}{ Occupations } \\
\hline Home services & $\begin{array}{l}0.293 * * * \\
(0.108)\end{array}$ & $\begin{array}{l}-0.060^{*} \\
(0.032)\end{array}$ & $\begin{array}{l}0.360 * * * \\
(0.105)\end{array}$ & $\begin{array}{l}-0.016 \\
(0.030)\end{array}$ \\
\hline Other non-traded & $\begin{array}{l}0.081 \\
(0.085)\end{array}$ & $\begin{array}{l}0.079 \\
(0.050)\end{array}$ & $\begin{array}{l}0.145^{*} \\
(0.081)\end{array}$ & $\begin{array}{l}-0.161 * * * \\
(0.055)\end{array}$ \\
\hline
\end{tabular}

Notes: Each entry is a separate regression. The dependent variable is the fraction of employment in each sector/occupation among the relevant education group (in a city-year cell). Entries are the coefficients on the fraction of college graduates in the city workforce. All specifications include year fixed effects, city-year controls (the proportion of women, blacks, Hispanics) and educationcity-year controls (the fraction of foreign-born; the fraction aged 18-24, 25-34, 35-44 and 44-55). In columns 5 and 6: two-step efficient generalized method of moments estimates; instruments are the interactions between a dummy for the presence of a land-grant college in the city and year dummies. First-stage coefficients and standard errors: Land Grant*year 1980: 0.041 (0.009); Land Grant*year 1990: 0.048 (0.011); Land Grant*year 2000: 0.063 (0.013); Land Grant*year 2005: 0.061 (0.012).

Standard errors (in parentheses) adjusted for serial correlation within MSA.

Source: IPUMS extracts from 1980-1990-2000 censuses and 2005 American Community Survey file. 
Table 7

Determinants of Relative Wage Growth at the bottom of the distribution

\begin{tabular}{|c|c|c|c|c|}
\hline (1) & (2) & (3) & (4) & (5) \\
\hline \multicolumn{5}{|l|}{ Regressors } \\
\hline$\left[\Delta \mathrm{Q}_{\mathrm{ct}}(.85)-\Delta \mathrm{Q}_{\mathrm{ct}}(.5)\right]$ & $\begin{array}{l}-.364 * * \\
(.158)\end{array}$ & $\begin{array}{l}-.474 * * \\
(.23)\end{array}$ & $\begin{array}{l}-.633^{* *} \\
(.27)\end{array}$ & $\begin{array}{l}.111 \\
(.325)\end{array}$ \\
\hline Home $_{\text {I }}^{\mathrm{I}}$ Share $_{\mathrm{t}-1}$ & $\begin{array}{l}-.050 \\
(.063)\end{array}$ & & $\begin{array}{l}-0.042 \\
(0.06)\end{array}$ & \\
\hline$\left[\Delta \mathrm{Q}_{\mathrm{ct}}(85)-\Delta \mathrm{Q}_{\mathrm{ct}}(50)\right] *$ Home $^{\mathrm{I}}$ Share $_{\mathrm{t}-1}$ & $\begin{array}{l}4.280 * * * \\
(1.623)\end{array}$ & & $\begin{array}{l}3.719 \\
(1.697)\end{array}$ & \\
\hline Home $_{-}^{\mathrm{O}}$ Share $_{\mathrm{t}-1}$ & & $\begin{array}{l}-.052 \\
(.085)\end{array}$ & & \\
\hline$\left[\Delta \mathrm{Q}_{\mathrm{ct}}(85)-\Delta \mathrm{Q}_{\mathrm{ct}}(50)\right] *$ Home $^{\mathrm{O}}$ Share $_{\mathrm{t}-1}$ & & $\begin{array}{l}4.909 * * \\
(2.16)\end{array}$ & & \\
\hline otherNT $_{-}^{\mathrm{I}}$ Share $_{\mathrm{t}-1}$ & & & $(0.06)$ & \\
\hline$\left[\Delta \mathrm{Q}_{\mathrm{ct}}(85)-\Delta \mathrm{Q}_{\mathrm{ct}}(50)\right] *$ otherNT $^{\mathrm{I}}$ Share $_{\mathrm{t}-1}$ & & & $\begin{array}{l}1.408 \\
(1.161)\end{array}$ & \\
\hline CollegeShare $_{t-1}$ & & & & $\begin{array}{l}-.018 \\
(.031)\end{array}$ \\
\hline$\left[\Delta \mathrm{Q}_{\mathrm{ct}}(85)-\Delta \mathrm{Q}_{\mathrm{ct}}(50)\right] *$ CollegeShare $_{\mathrm{t}-1}$ & & & & $\begin{array}{l}-.291 \\
(.589)\end{array}$ \\
\hline
\end{tabular}

Notes: The dependent variable is the change in log real hourly wages at the $15^{\text {th }}$ percentile of the wage distribution net of change in log real hourly wages at the median. 242 MSA's and three periods (19801990, 1990-2000, 2000-2005) are considered, for a total of 726 observations in each regression. The explanatory variables include the change in log real hourly wages at the $85^{\text {th }}$ percentile of the wage distribution net of changes in log real hourly wages at the median wage percentiles $\left[\Delta Q_{c t}(85)-\Delta Q_{c t}(50)\right]$, the share of college graduates in a city in the base year (1980, 1990 and 2000 respectively), the share of workers with wages below the $15^{\text {th }}$ percentile employed in home services (Home ${ }_{-}^{I}$ Share) or in other nontradeable services (otherN $t_{-}^{I}$ Share) in the base year. The superscript (I or O) refers on the classification used (industry or occupation). All regressions include period fixed effects.

Robust standard errors (in parentheses).

Source: 1980-1990-2000 censuses and 2005 ACS file. 


\section{Figure 1}

Low-skill and high-skill intensive services

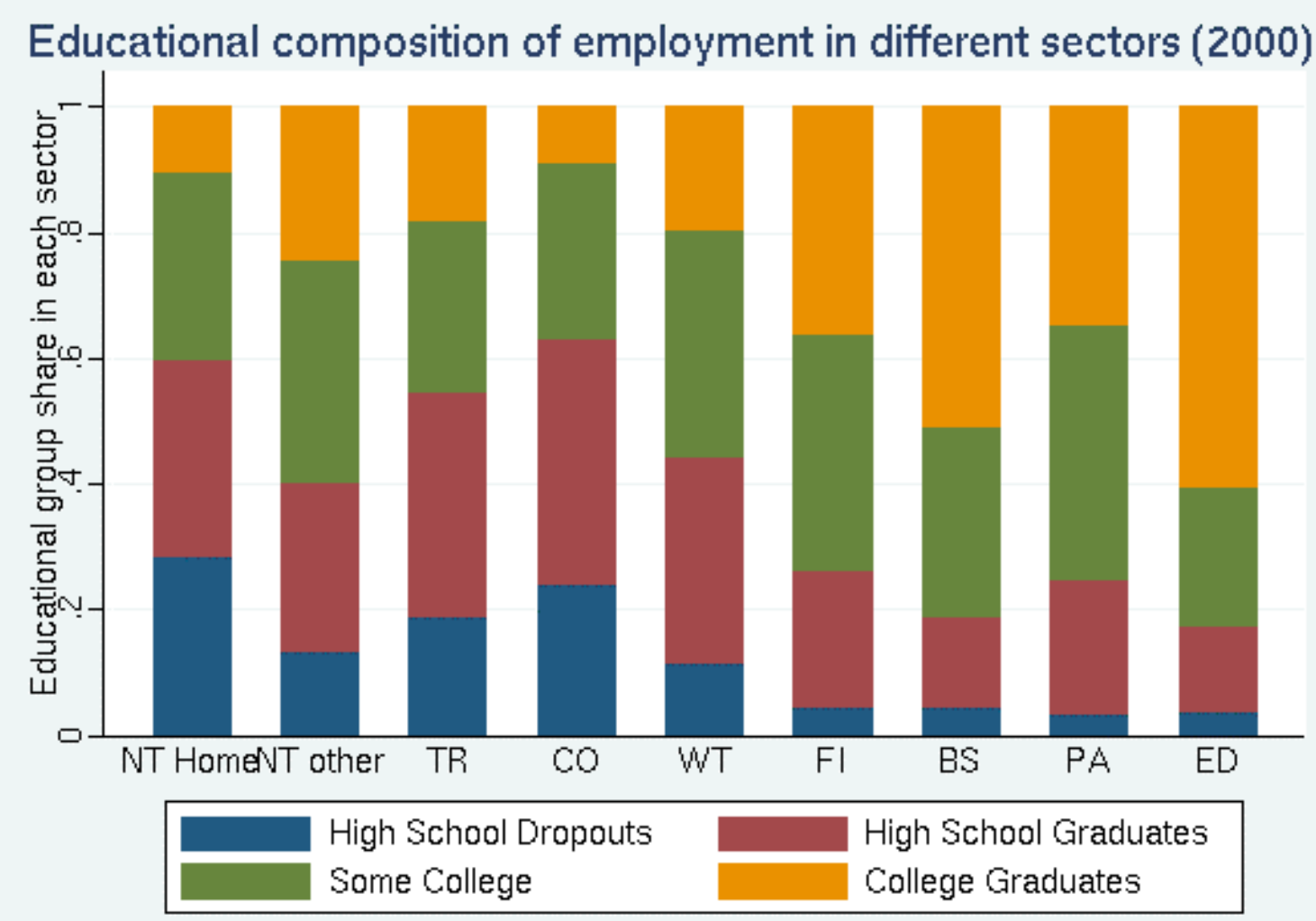

Legend: NT: clearly non-traded sectors/occupations, of which NT Home includes services that can be thought as substitutes of home production (e.g. personal and cleaning services); TR: clearly traded (agriculture, mining and manufacturing); CO: construction; WT: wholesale, transportation, utilities; FI: financial services; BS: business services; PA: Public Administration; ED: education (see Tables A1-A2).

Source: 2000 census. 


\section{Figure 2}

\section{Immigrant intensive sectors}

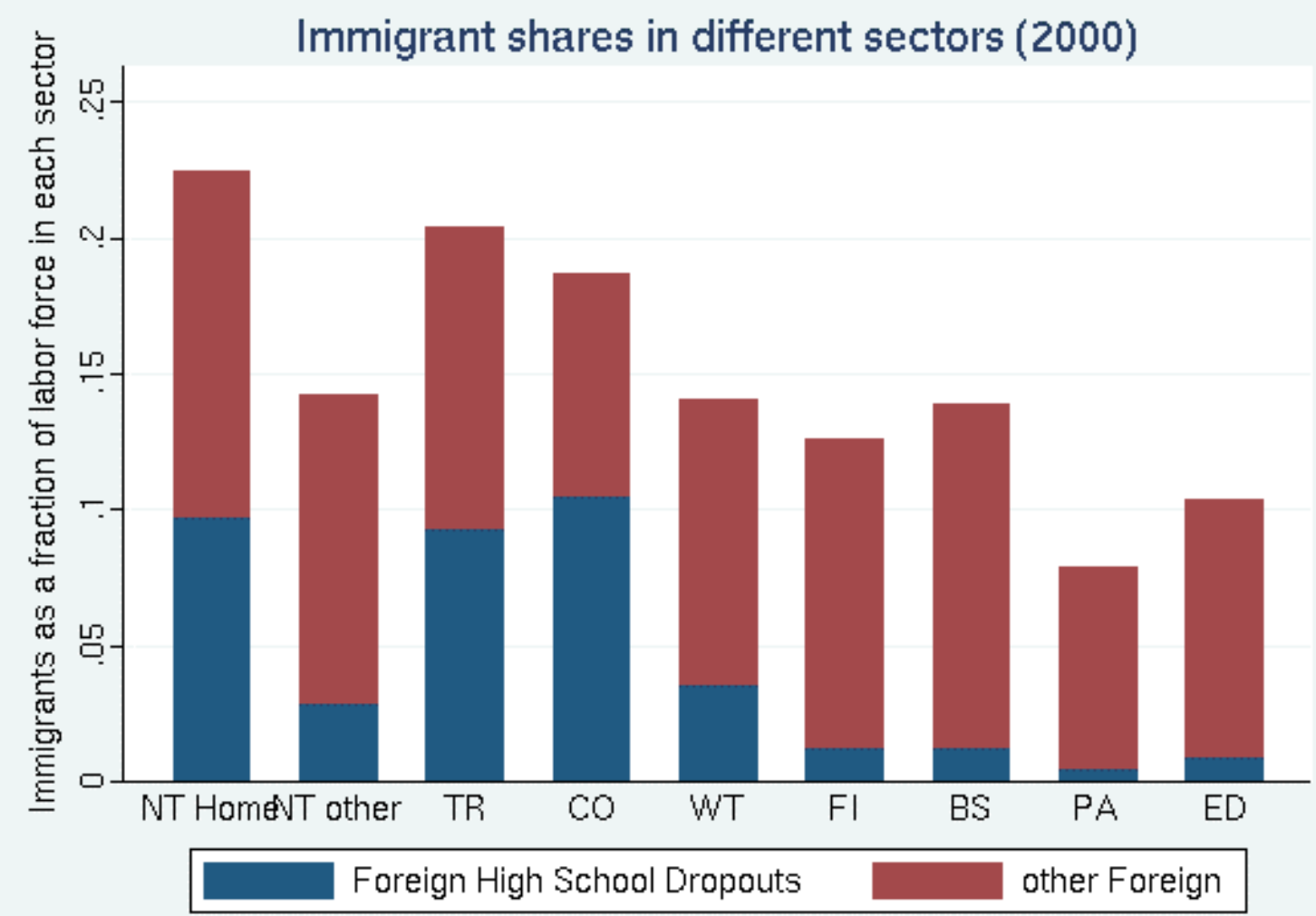

Legend: NT: clearly non-traded sectors/occupations, of which NT Home includes services that can be thought as substitutes of home production (e.g. personal and cleaning services); TR: clearly traded (agriculture, mining and manufacturing); CO: construction; WT: wholesale, transportation, utilities; FI: financial services; BS: business services; PA: Public Administration; ED: education (see Tables A1-A2).

Source: 2000 census. 


\section{Figure 3}

Are home production substitutes superior goods?

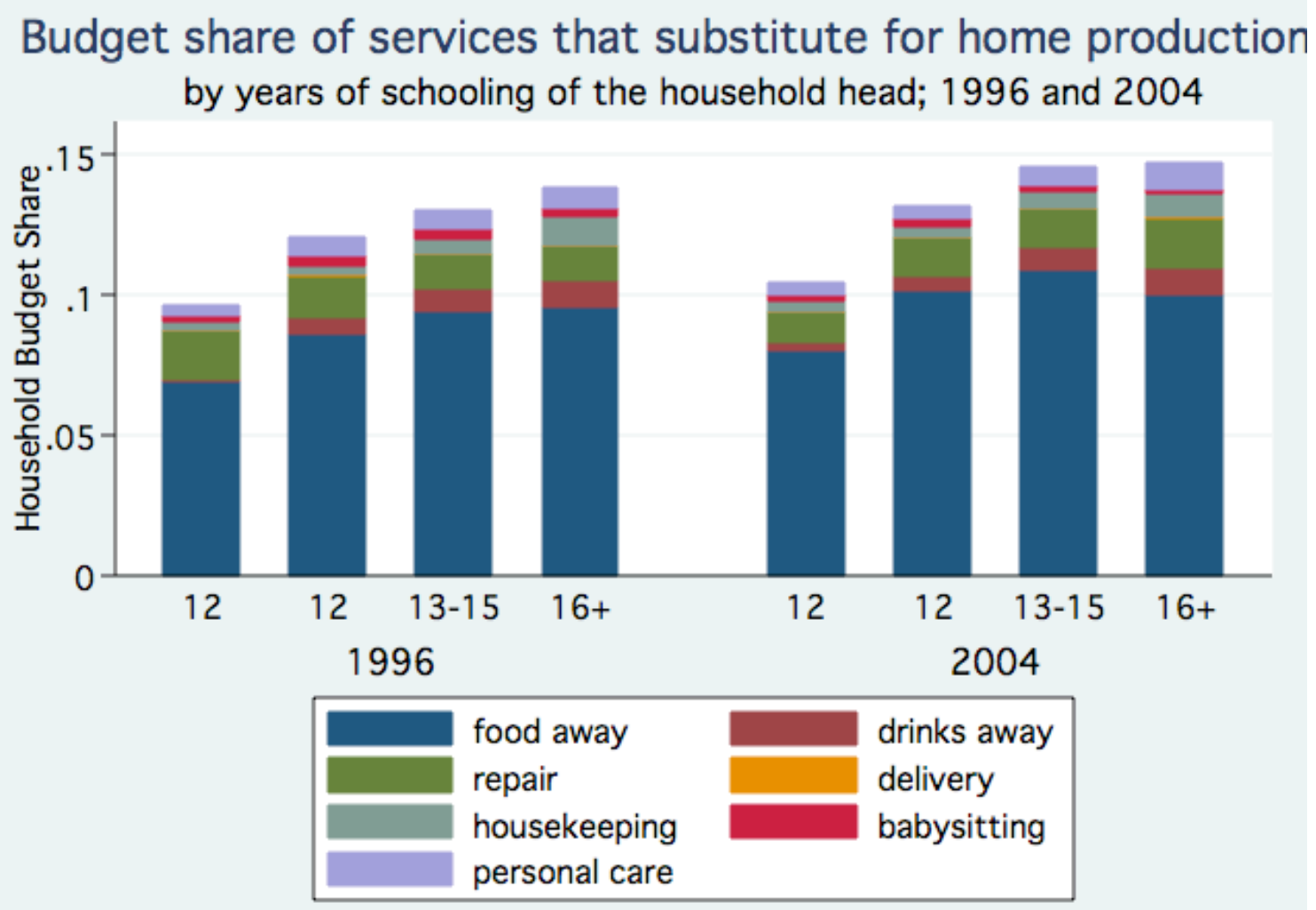

Note: All figures are weighted using weights provided by the Bureau of Labor Statistics. The sample is restricted to households headed by individuals at least 18 and no more than 65 who worked for salary in the twelve months before the interview.

Source: 1996 and 2004 CEX Diary Surveys. 


\section{Figure 4}

Differences across family types

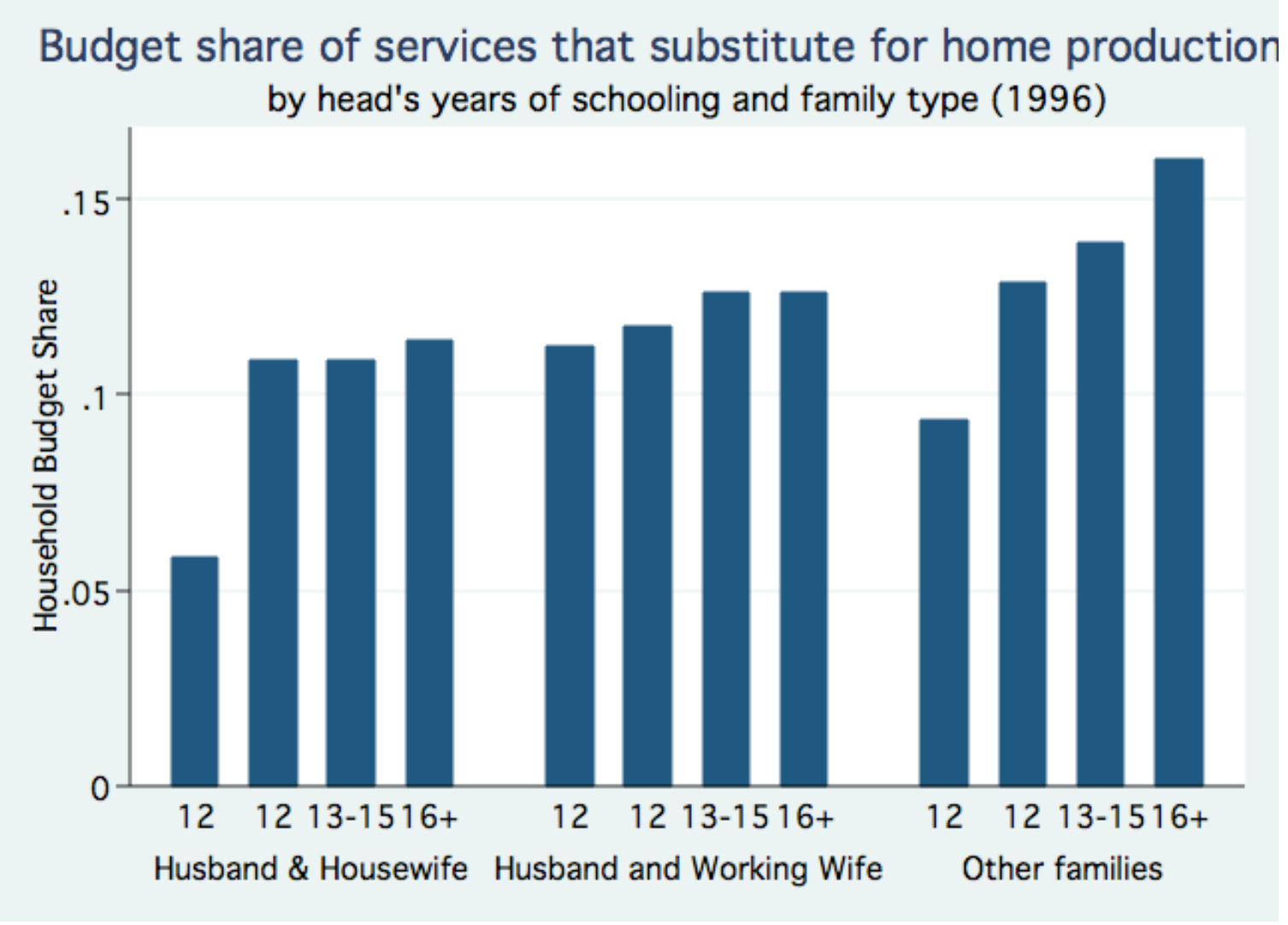

Note: All figures are weighted using weights provided by the Bureau of Labor Statistics. The sample is restricted to households headed by individuals at least 18 and no more than 65 who worked for salary in the twelve months before the interview.

Source: 1996 and 2004 CEX Diary Surveys. 


\section{Figure 5}

Correlation between log hourly wages of the head and household budget share in home services

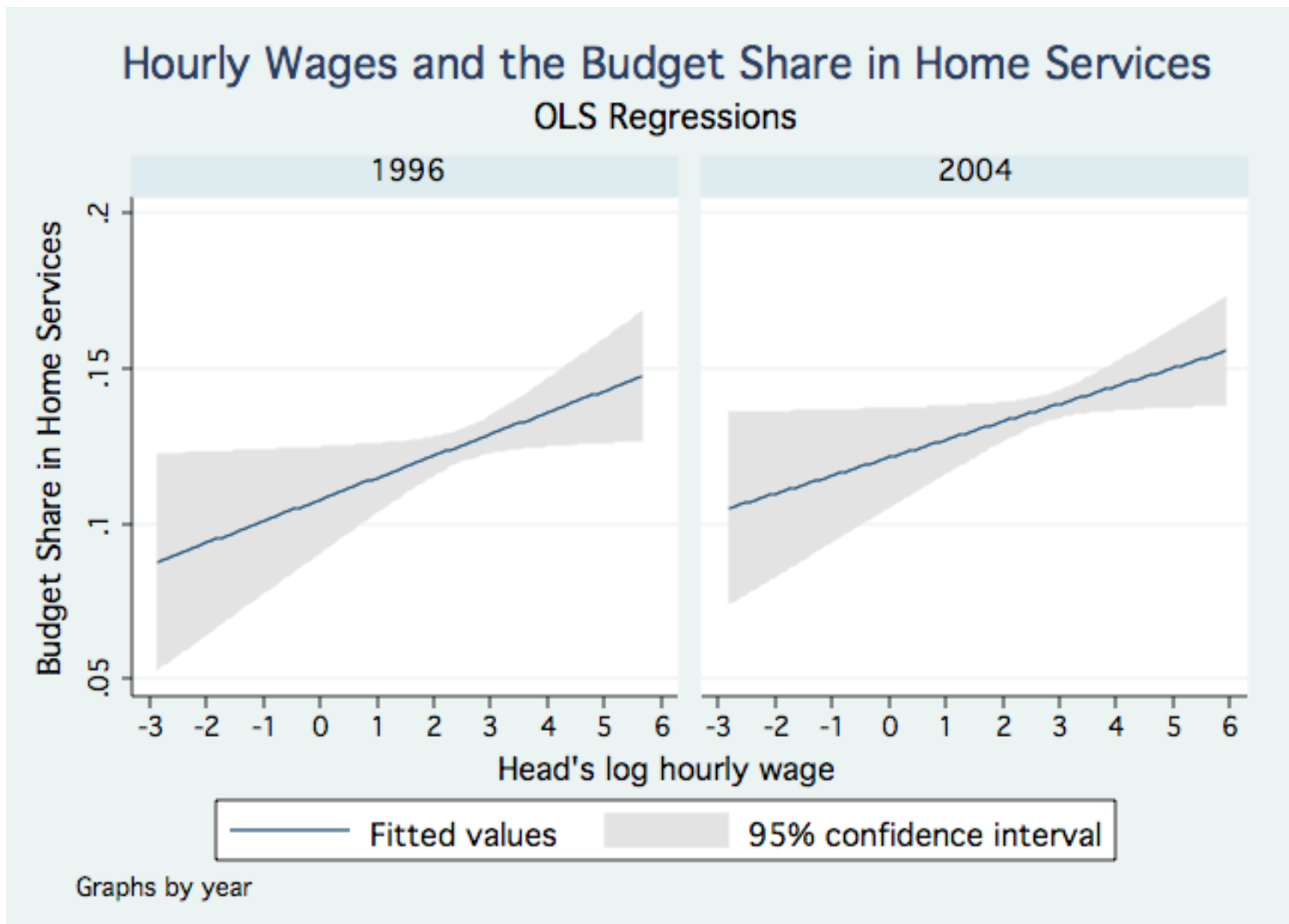

Note: OLS fit and 95\% confidence interval. The slope coefficient is 0.006 in both years (standard errors of .003 and 0.002 in 1996 and 2004 respectively).

Source: 1996 and 2004 CEX Diary Surveys. 
Table A1

Assigning traded/non-traded status to industries

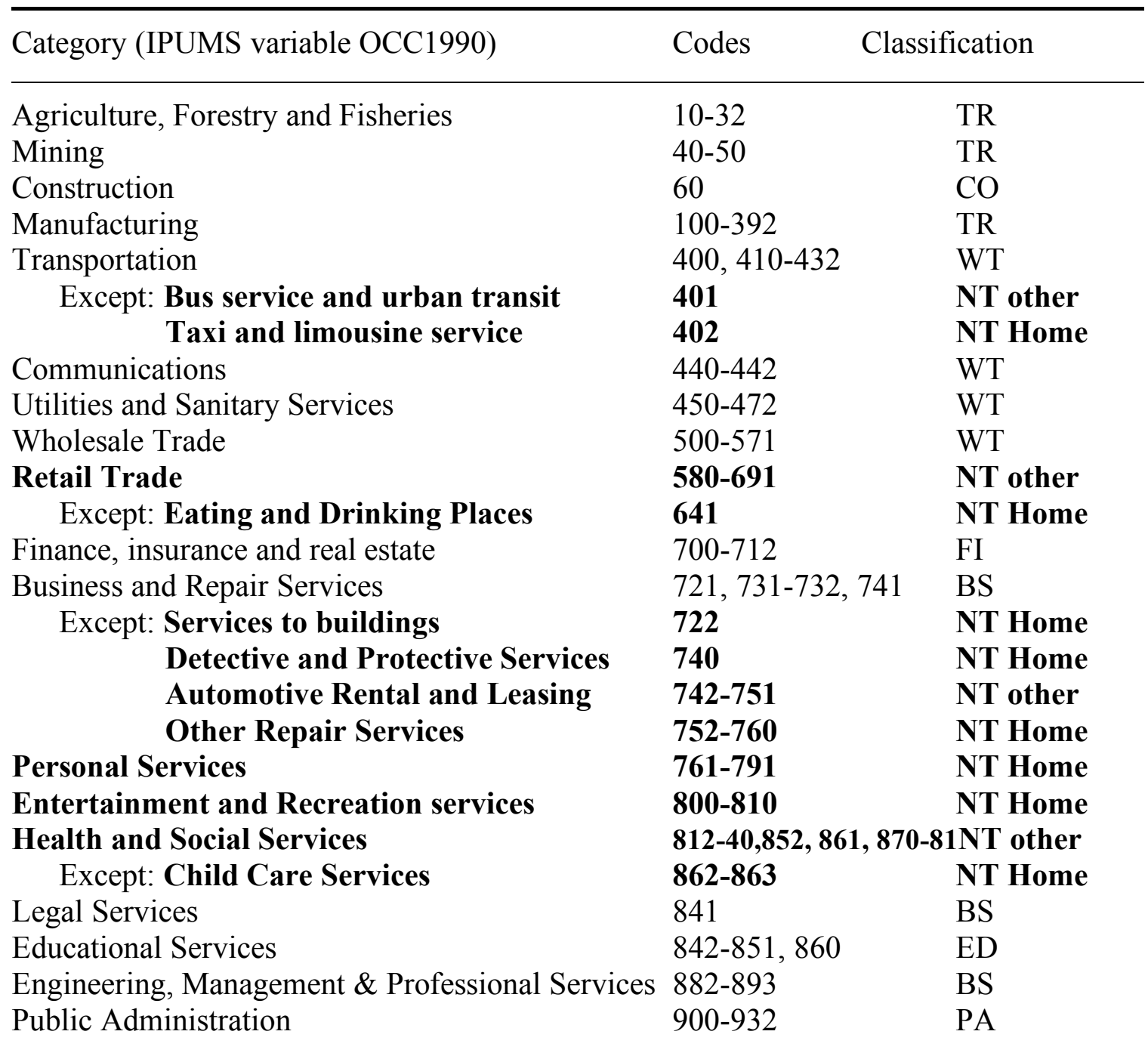

Notes: The codes refer to the IPUMS variable IND1990, which is a modified version of the 1990 Census Bureau industry classification scheme and provides a consistent set of industries codes for Census years 1980, 1990 and 2000, and for the American Community Service data from 2001 on. IND1990 was created in the IPUMS using a series of technical papers published by the Census Bureau that provide detailed analyses of how the industrial coding scheme for each census year differed from the scheme used during the previous census year. These industrial "crosswalks" are based on samples of cases that are "double coded" into the industrial schemes of the current and previous census year. The original Census Bureau crosswalks are available via links, at http://usa.ipums.org/usa/chapter4/chapter4.shtml\#crosswalks

Legend: NT: clearly non-traded; TR: clearly traded; CO: construction; WT: wholesale, transport and utilities; FI: financial services; BS: business services; PA: Public Administration; ED:

education. 
Table A2

Occupations that deliver market substitutes for home production

Category (IPUMS variable OCC1990)

Codes

\section{NT Home}

Private household occupations

$405-407$

Protective service occupations

$415-427$

Food preparation and service occupations

$434-444$

Cleaning and building service occupations (except households)

$448-455$

Personal service occupations

$456-465$

Gardeners

486

Animal caretakers (except on farms)

487

Laundry workers

748

Taxi cab drivers and chauffeurs

809

Garbage and recyclable material collectors

875

\section{NT other}

Sales occupations

$243-283$

Information clerks

$316-323$

Health service occupations

$445-447$

Washing, cleaning and pickling machine operators

764

Bus drivers

$808-813$

Freight, stock and material handlers (except garbage collectors)

$875-889$

Notes: The codes refer to the IPUMS variable OCC1990, which is a modified version of the 1990 Census Bureau occupational classification scheme that provides a consistent set of occupations codes for Census years 1980, 1990 and 2000, and for the American Community Service data from 2001 on.

Specifics on the methods applied to insure consistency can be found in the BLS Working Paper "Proposed Category System for 1960-2000 Census Occupations", Peter B. Meyer and Anastasiya M. Osborne, U.S. Bureau of Labor Statistics, Working Paper 383, September 2005, available at http://usa.ipums.org/usa/chapter4/OCCBLS_paper.pdf 
Table A3

Assigning expenditure items to non-traded service categories

Category

Food away from Home

Drink away from Home

Repair and Maintenance

Delivery Services

Babysitting Services

Housekeeping Services
Universal Classification code (UCC): 1996 files

190110 Lunch at restaurants, cafes, etc...

190210 Dinner at restaurants, cafes, etc...

190310 Snacks and non alcoholic beverages, including tip

190320 Breakfast and brunch at restaurants, cafes, etc...

190901 Food or board, at school and rooming/boarding houses

200510 Beer and ale away from home

200520 Wine away from home

200530 Other alcoholic beverages away from home

230000 Repair, maintenance, and improvements for built in dishwasher, garbage disposal, and range hood

230110 Maintenance of property, including items such as ceiling repair, black top, brick, or masonry work, air conditioner repair, roof and awning repair, house painting, papering, chimney cleaning, electrical inspection, furnace inspection and repair, wiring, pest control, carpenter, plumber, etc...

230140 Repair disposal, dishwasher, range hood

270210 Water and sewerage maintenance

270410 Garbage, trash collection

270900 Septic tank cleaning

340610 Repair of television, radio, and sound equipment, excluding installed in vehicles

340620 Repair of household appliances; including stove, vacuum, washer, dryer, sewing machine, refrigerator, and calculator; excluding garbage disposal, range hood, and built-in dishwasher

340630 Furniture repair, refurnishing, or reupholstery

340903 Miscellaneous home services and small repair jobs not already specified

340913 Repair and alterations of miscellaneous household equipment, furnishings, and textiles

440110 Shoe repair and other shoe services

440130 Alteration, repair, tailoring of apparel and accessories

440150 Watch and jewelry repair

340120 Delivery services

340210 Babysitting or other home care for children

340310 Housekeeping service, such as housekeeping, cooking, maid service, interior decorating, and carpet and upholstery cleaning services

340410 Gardening and lawn care services, such as mowing, tree services, fertilizing, and yard work 
340510 Moving, storage, and freight express

340520 Non-clothing household laundry or dry cleaning not coin operated

440210 Apparel laundry and dry cleaning not coin operated

Personal Care Services

650110 Personal care services for females, including haircuts 650210 Personal care services for males, including haircuts

Notes: The classification is based on the Universal Classification Code (UCC) Titles in the 1996 CEX Expenditure files. Some UCC have been added over time. For example, the 2004 classification includes more detailed codes on meals away from home. 